\title{
12. MINERALOGY AND CHEMISTRY OF SULFIDE DEPOSITS DRILLED FROM HYDROTHERMAL MOUND OF THE SNAKE PIT ACTIVE FIELD, MAR ${ }^{1}$
}

\author{
J. Honnorez, ${ }^{2}$ C. Mevel, ${ }^{3}$ and B. M. Honnorez-Guerstein ${ }^{2}$ \\ With chemical analyses by H. P. Tomschi ${ }^{4}$
}

\begin{abstract}
The Snake Pit active hydrothermal field was discovered at $23^{\circ} 22^{\prime} \mathrm{N}$ on the Mid-Atlantic Ridge during ODP Leg 106. Among the ten holes drilled in the mound at the foot of an active chimney, only three $(649 \mathrm{~B}, 649 \mathrm{~F}$, and $649 \mathrm{G})$ had substantial recovery, and produced cores of unconsolidated hydrothermal deposit made up of porous sulfide fragments with minor talc pellets and biological debris, and a few pieces of brassy massive sulfides.

Eight representative samples from the 6.5 -m-long core from Hole 649B were analyzed for bulk chemistry, both by XRF (major elements) and NAA (trace elements). Major elements average compositions show high Fe (36 wt\%), $\mathrm{S}(37 \mathrm{wt} \%)$, and $\mathrm{Cu}(12 \mathrm{wt} \%)$ contents, and minor $\mathrm{Zn}(6.7 \mathrm{wt} \%)$, reflecting a mostly high-temperature deposit. Trace elements are characterized by a high Au content $(600 \mathrm{ppb})$ which could express the maturity of the mound.

Mineralogical assemblages show evidence of sequential precipitation, and absence of equilibrium. Major sulfide phases are pyrrhotite, pyrite, $\mathrm{Fe}, \mathrm{Cu}$ sulfides, marcasite, and sphalerite. Three types of samples are distinguished on the basis of textures and mineral assemblages: type 1, rich in pyrrhotite, with approximately equivalent amounts of $\mathrm{Cu}, \mathrm{Fe}$ sulfides, and sphalerite and minor pyrite; type 2, rich in $\mathrm{Cu}, \mathrm{Fe}$ sulfides, which are cubic cubanite with exsolutions and rims of chalcopyrite; and type 3, essentially made up of sphalerite. Type 2 samples likely represent fragments of the inner chimney wall. The presence of talc intergrown with cubic cubanite/chalcopyrite in one big piece from Hole $649 \mathrm{G}$ is probably related to mixing of the hydrothermal fluid with seawater.
\end{abstract}

\section{INTRODUCTION}

Evidence of hydrothermal activity near or at slow-spreading axes was restricted until 1985 to two rather limited areas of the Mid-Atlantic Ridge (MAR): the small inactive vents in fracture zone A of the FAMOUS area, near $37^{\circ} \mathrm{N}$ (Hoffert et al., 1978) and the TAG area near $26^{\circ} \mathrm{N}$ (Thompson et al., 1985, and references therein). At both locations, low-temperature precipitates were essentially composed of Mn-hydroxides and green clay mineral mixtures of celadonite and nontronite. Both deposits were further characterized by low-transition trace metals contents (i.e., other than $\mathrm{Fe}$ and $\mathrm{Mn}$ ); the lowest levels were measured in the clays (Thompson et al., 1985). It was then thought (Temple et al., 1979) that only low-temperature oxides and silicates were present at slow-spreading-ridge hydrothermal sites which lacked high-temperature sulfides, whereas the converse was true at fast- or intermediate-spreading ridges.

To explain the lack of high-temperature hydrothermal activity on the seafloor at slow-spreading ridges, Scott et al. (1979) and Temple et al. (1979) had concluded that the geometry of the hydrothermal circulation and, hence, the location and nature of the hydrothermal products, were related to spreading rate. Slow-spreading ridges are characterized by important vertical tectonic movement often resulting in a large axial rift valley. Scott et al. (1979) had assumed that the absence of high-temperature hydrothermal activity and sulfide deposits was "related to more closely spaced fracturing and faulting which results in higher rock/water ratios."

\footnotetext{
I Detrick, R., Honnorez, J., Bryan, W. B., Juteau, T., et al., 1990. Proc. $O D P$, Sci. Results, 106/109: College Station, TX (Ocean Drilling Program).

${ }^{2}$ Institut de Géologie et Centre de Géochimie de la Surface, Université Louis Pasteur, 1 rue Blessig, 67084 Strasbourg Cedex. France.

${ }^{3}$ CNRS URA D0736 Pétrologie-Magmatologie-Métallogénie, UPMC, 4 place Jussieu, 75252 Paris Cedex 05, France.

${ }^{4}$ Mineralogisch-Petrographisches Institut, Köln Universität, 218 Altenburger Strasse, 5000 Köln, F.R.G.
}

This high permeability could allow cold and oxygenated seawater to mix with hot and reduced hydrothermal solutions more deeply inside the crust instead of mixing at or near the seafloor and to form disseminated or stockwork deposits within the basaltic layer. On the other hand, MacDonald (1982) suggested that "the contrast in crustal generation process (between the EPR and the MAR) as a function of spreading rates is likely to affect the manifestation of hydrothermal activity and sulfide deposition." This author links the venting of high-temperature solutions and the sulfide deposition on the seafloor of fast- and intermediate-spreading $(>6$ $\mathrm{cm} / \mathrm{yr}$ ) ridges to the presence of steady-state magma chambers at shallow crustal depths. "At slow spreading ridges this high-temperature hydrothermal activity may occur only rarely at the seafloor but may occur at depth within the dike and flow sequences" (MacDonald, 1982).

All these discussions were cut short in 1985 by the discovery of high-temperature hydrothermal activity in 1985 at two locations along the MAR: the Snake Pit hydrothermal area, at $23^{\circ} \mathrm{N}$, south of the Kane fracture zone (ODP Leg 106 Scientific Party, 1986) and the already-mentioned TAG area (Rona et al., 1986). Since then, new data on the chemistry of the water column along the MAR have shown the presence of hydrothermal plumes at other locations (Bougault et al., 1988) and suggest that high-temperature hydrothermal activity is also widespread along slow-spreading ridges.

This paper concerns the sulfides drilled in the Snake Pit hydrothermal field by the JOIDES Resolution during ODP Leg 106 in 1985.

\section{GEOLOGICAL SETTING}

The Snake Pit active hydrothermal field was discovered during ODP Leg 106 (ODP Leg 106 Scientific Party, 1986). Hydrothermal activity had been suggested during the site survey preparation to ODP Leg 106 by deep towed camera photographs which showed stained sediments and biological debris (Detrick et al., 1985; Kong et al., 1985). During Leg 


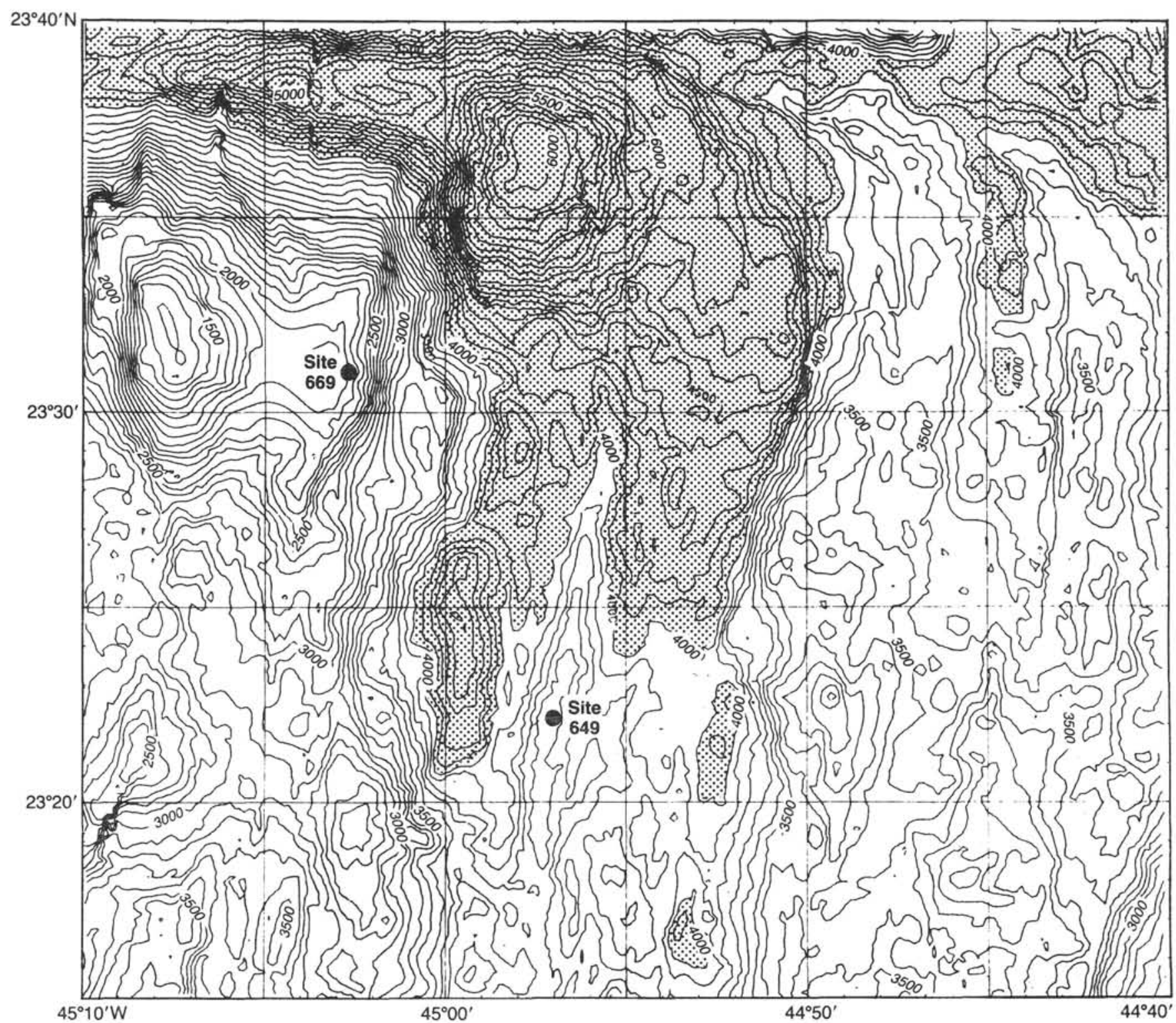

Figure 1. Seabeam bathymetry map of eastern intersection of the Mid-Atlantic Ridge rift valley and the Kane fracture zone (Detrick et al., 1985), showing location of the Snake Pit hydrothermal field (Site 649).

106, a survey of this area with a camera mounted on the drill string discovered the hydrothermal field, with at least one active "black smoker" vent (ODP Leg 106 Scientific Party, 1986) and intense biological activity (sea anemones, shrimp, and eels). The field is located in the rift valley of the MidAtlantic Ridge near $23^{\circ} 22.08^{\prime} \mathrm{N}, 44^{\circ} 57.00^{\prime} \mathrm{W}$, on a narrow constructional ridge of pillow-lavas, which is part of the neovolcanic ridge (Fig. 1).

A preliminary geological map was tentatively drawn from the camera survey observations (ODP Leg 106 Scientific Party, 1986). It showed that the vent field is oriented eastwest, and its total area is probably more than $40,000 \mathrm{~m}^{2}$. It consists of at least one active vent and several extinct ones. Light colored hydrothermal sediments are abundant around the vents. Ten holes were drilled in the area, including five in the mound forming the pedestal of the active chimney. Despite the low recovery, the bore holes gave a third dimension to the field and permitted constructing a profile through the mound topped by the active chimney (Fig. 2).
In 1986, one single Alvin dive during a cruise in the MARK area brought more information on the Snake Pit field. The Alvin investigation showed that the area of active venting is about $200 \mathrm{~m}$ long $\times 20 \mathrm{~m}$ wide and up to $40 \mathrm{~m}$ high (Karson and Brown, 1988; Thompson et al., 1988). The shape of the vent area is similar to that inferred from the camera survey and sketched in Figure 2. Anhydrite with disseminated sulfides occurs in the top third of some active chimneys.

In 1988, 11 dives were conducted with the submersible Nautile on the Snake Pit Ridge and yielded a detailed geological map of the area (Gente et al., 1988; Mével et al., 1989). In particular, the map shows the relation between vent locations and faulting. The new set of samples collected during this cruise is currently being studied.

\section{SAMPLING}

The sulfide samples studied come from the three holes which had any substantial recovery: $649 \mathrm{~B}, 649 \mathrm{~F}$, and $649 \mathrm{G}$ (see Fig. 2 for locations relative to the active chimney). Thirty 


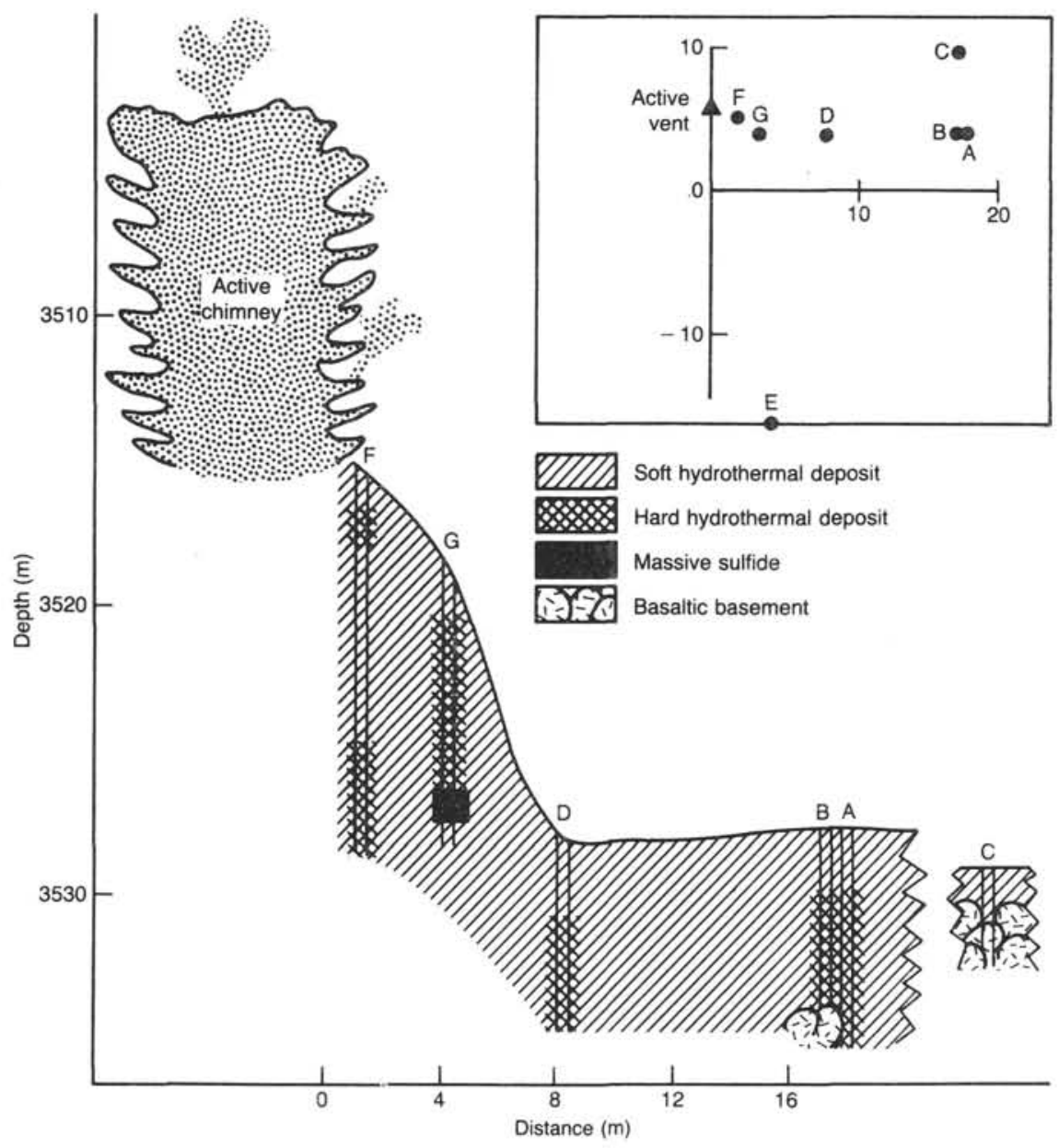

Figure 2. Cross section of hydrothermal deposit near large black smoker in vent field based on drilling results at Site 649. Inset shows position of drill holes relative to the active vent (after ODP Leg 106 Scientific Party, 1986).

polished sections and polished thin sections have been studied of a collection of 106 samples: 26 sections are from Hole 649B, 1 from Hole $649 \mathrm{~F}$, and 3 from Hole 649G.

Hole 649B, about $17 \mathrm{~m}$ away from the chimney, penetrated $6.5 \mathrm{~m}$ into the mound and produced $6 \mathrm{~m}$ of unconsolidated hydrothermal deposits representing $92 \%$ recovery. The original stratigraphy was not preserved because of technical problems in recovering the core from the metallic core liner. However, a systematic decrease in grain size was observed from bottom to top of the core and may be significant. The whole section consists of a black material composed almost exclusively of sulfide fragments, with minor grayish clay-like pellets, glass shards, and biological debris (mostly shrimp antennae and legs). All the biggest fragments are concentrated at the bottom (Sample 649B-1D-8) and never exceed a few centimeters in size. It is impossible to know whether this represents the actual size of the fragments in the mound or if these were cuttings from bigger fragments (as suggested by observations from the Alvin and the Nautile) broken during the drilling process. About 30 fragments of sulfides and the biggest clayish pellets were selected for petrological studies.

Hole $649 \mathrm{~F}$, right at the foot of the active chimney, penetrated $13 \mathrm{~m}$ into the mound but recovered only one small sample in the core catcher: it is made up of chlorite and a sulfide aggregate very similar to the massive sulfide of Hole 649G.
Hole 649G, $4 \mathrm{~m}$ away from the chimney, penetrated $9 \mathrm{~m}$ into the mound but produced only a $0.15 \mathrm{~m}$ core. It consists mostly of three brassy massive sulfide blocks and a piece of grayish talc intergrown with sulfides.

\section{BULK SAMPLE CHEMISTRY}

Eight representative samples, weighing roughly $50 \mathrm{~g}$, were taken from Hole 649B for bulk chemical analyses. The samples were scooped from the central part of each of the eight 1.5 - $\mathrm{m}$-long sections of plastic liner halves in which the 6 $\mathrm{m}$-long core had been spread. These samples were essentially made up of sulfide fragments with rare talc pellets. Their grain size decreased from bottom of the core (Sample 649B-1D-8) where the fragment size ranges from a few millimeters up to 4 $\mathrm{cm}$ long in one exceptionally large fragment, to the top of the core where the fragments are silt sized (Sample 649B-1D-1).

One sample from the Galapagos Spreading Center was also analyzed for comparison because the literature indicated that this deposit has a similar composition to that of the average sample from Hole 649B of the Snake Pit hydrothermal field (Bischoff et al., 1983; Malahoff, 1982).

\section{Analytical methods}

The analyses were carried out by H. P. Tomschi at the Mineralogisch-Petrographisches Institut of the Köln Universität, Federal Republic of Germany. 
Table 1. Bulk sample chemical composition of ODP Hole 649B sulfide samples.

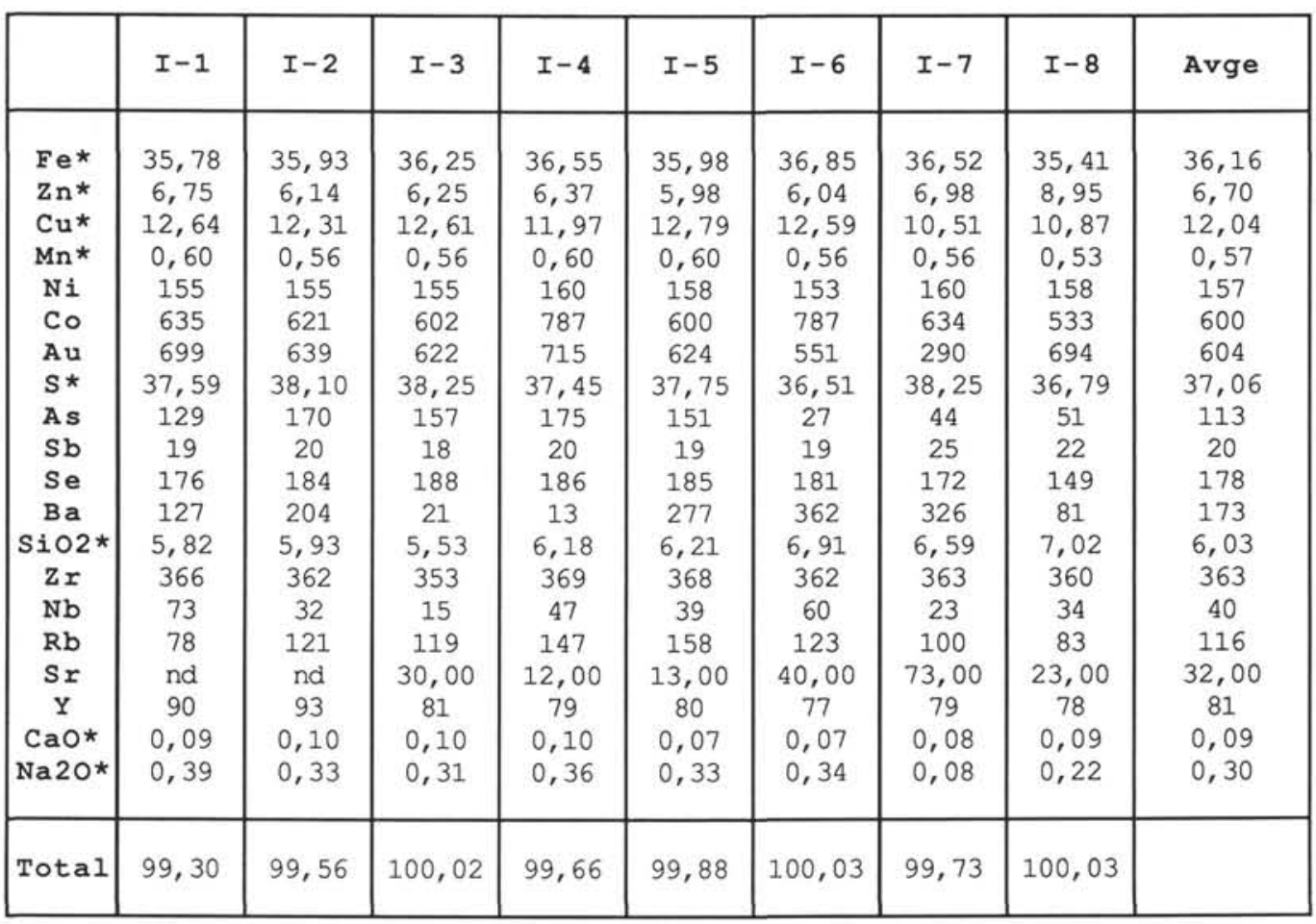

All element contents in ppm except the majors marked * which are in \% and $\mathrm{Au}$ which is in ppb; nd = not detected.

1. $\mathrm{Zn}, \mathrm{Cu}, \mathrm{Ni}, \mathrm{Rb}, \mathrm{Sr}, \mathrm{SiO}_{2}, \mathrm{CaO}, \mathrm{MnO}, \mathrm{Na}_{2} \mathrm{O}$, and $\mathrm{S}$ were analyzed by XRF. Due to the expected high concentrations of $\mathrm{Zn}$ and $\mathrm{Cu}$, two different pellets were pressed: one containing $200 \mathrm{mg}$ of sample and the other containing approximately $1 \mathrm{~g}$. The matrix of the pellets consisted of dried $\mathrm{H}_{3} \mathrm{BO}_{3}$ and an internal standard consisting of $\mathrm{Ag}, \mathrm{Nd}$, and $\mathrm{Te}$ (for correction of matrix effects). Standards were prepared in the same way and measured under the same instrumental conditions as the samples. $\mathrm{Zn}$ and $\mathrm{Cu}$ were analyzed on the first set of pellets (containing $200 \mathrm{mg}$ of sample) whereas all other elements were done from the second set of pellets. The precision of the XRF method is $5 \%-10 \%$. The analyses were repeated three times and the values represent means of the three runs on the same pellets. Due to lack of material the sample from the Galapagos Spreading Center was only analyzed by NAA (Neutron Activation Analysis).

2. $\mathrm{Au}, \mathrm{As}, \mathrm{Sb}, \mathrm{Se}, \mathrm{Co}, \mathrm{Na}_{2} \mathrm{O}$, and $\mathrm{Fe}$ were analyzed by NAA in all of the nine samples. The conditions were as follows. All elements were determined against single-element standards on high purity $\mathrm{Al}$. For cross checking, they were also compared with the standard Dr-N, which is a diorite (Geostandards Newsletter, 1984, Vol VIII, Special Issue) and a house internal standard (B-Bir). Approximately $200 \mathrm{mg}$ of each sample was irradiated in the research reactor "DIDO" of the Nuclear Research Center at Jülich, Federal Republic of Germany. Irradiation conditions were the following:

Thermal Neutron flux $=0.8-1.0 \times 10^{13} \mathrm{n} / \mathrm{cm}^{2} \mathrm{~s}$

$$
\text { Irradiation time }=12 \mathrm{hr}
$$

On 6,14 , and 50 days after the end of their radiation period, the samples and the standards were measured by a coaxial $\mathrm{Ge}(\mathrm{Li})$-detector $\left(200 \mathrm{~cm}^{3}\right)$ for a period of $4,000 \mathrm{~s}$ or $10,000 \mathrm{~s}$ for samples with low activities. The resolution of the $\mathrm{Ge}(\mathrm{Li})$-detector is $2.5 \mathrm{keV}$ at an energy of $1332 \mathrm{keV}$. The precision of the analyses by NAA is $+5 \%-8 \%$ (st. dev.) for the concentrations encountered in the analyzed samples.

\section{Results}

The representativity and homogeneity of our samples were confirmed by the narrow range of elemental variations among the eight samples analyzed. Table 1 presents the chemical analyses for 20 elements of the eight samples from Hole 649B and the average composition calculated on the basis of the eight analyses. The latter is then fully representative of the 6.5 -m-thick layer of sulfides drilled in Hole 649B before hitting the basaltic basement.

In Table 2 the average chemical composition of the eight samples from Hole 649B is compared to those of oceanic sulfide deposits. It includes the analyses by NAA of the Galapagos Spreading Center sample of this study (column 12). One must, however, keep in mind that it is quite difficult to compare our analyses which are representative of a 6-m-long section through a sulfide mound of the Snake Pit area with most of the published analyses which were presented as representative or called "assays" by the authors and whose totals were reasonably high enough. The most representative ones are probably the composite sample from the Galapagos Spreading Center (Table 2, column 11) which is an assay carried out on a sample made up of "seven samples taken from both the trench dug up on top of the massive sulfide and from individual chimneys" (Malahoff, 1982) and the composite sample from EPR (Table 2, column 9), "composed of all available sulfide material from $21^{\circ} \mathrm{S}^{\prime}$ (Bäcker et al., 1985). These can be compared with our average bulk chemical analyses of Hole 649B (Table 2, column 1).

\section{Major elements}

The major components of the calculated average mound sample of the Snake Pit hydrothermal area are sulfur $(37.6 \%)$ and iron $(36.2 \%)$, then copper $(12 \%)$, which reflects the abundance of Fe sulfides (mainly pyrite and, to a lesser extent, pyrrhotite and marcasite) and $\mathrm{Cu}, \mathrm{Fe}$ sulfides (chalcopyrite and cubic cubanite, also called isocubanite or ISS) in the mound material. Zinc content is much lower (6.7\%). This 
Table 2. Comparison between the average bulk sample chemical composition of the Snake Pit hydrothermal deposit and those of other present-day seafloor deposits.

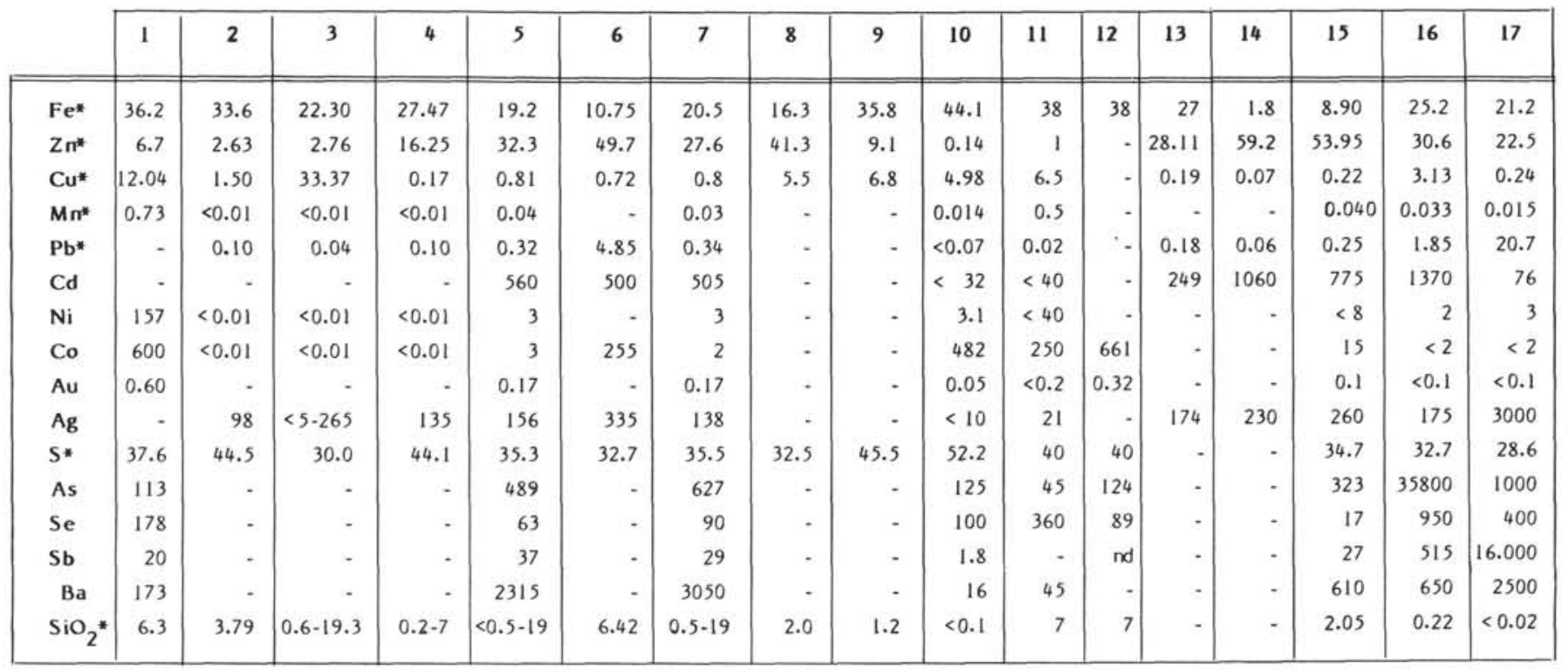

1. Calculated average of eight representative samples from the Snake Pit hydrothermal area sulfide mound (this paper).

2. Calculated average of four "representative" Fe sulfide-chimney fragments from the TAG hydrothermal area (Thompson et al., in 1988).

3. Calculated average of three "representative" Cu-Fe sulfide-chimney fragments-same locality as above (Thompson et al., 1988).

4. Calculated average of two "representative" $\mathrm{Zn}$-Fe sulfide chimney fragments-same locality as above (Thompson et al., 1988).

5. Calculated average of three massive sulfide samples from an inactive basal mound of the EPR at $21^{\circ} \mathrm{N}$ (Bischoff et al., 1983).

6. Calculated average of two massive sulfide samples with tubular structure from a basal mound of the EPR at $21^{\circ} \mathrm{N}$ (Hekinian et al., 1980).

7. Calculated average of two mound samples from EPR at $21^{\circ} \mathrm{N}$ (Zierenberg et al., 1984).

8. Zoned chimney fragment from the EPR at $18^{\circ} 5^{\prime} \mathrm{S}$ (Bäcker et al., 1985).

9. Composite massive sulfide sample from the EPR at $21^{\circ} 5^{\prime} \mathrm{S}$ (Bäcker et al., 1985).

10. One massive sulfide sample analysis from the Galapagos Rift (Bischoff et al., 1983).

11. "Composite sample" of seven fragments of a sulfide mound and individual chimneys" from the Galapagos Rift (Malahoff, 1982).

12. One fragment of a large massive sulfide sample of a "smaller inactive chimney" from the Galapagos Rift (this paper).

13. Average of three bulk samples of "Type A massive sulfide from an active vent" of the Juan de Fuca Ridge (Normark et al., 1983). Low totals but the analysis did not include $\mathrm{S}$.

14. One bulk sample of "Type B spongy sulfide" from the same locality as 13 (Normark et al., 1983).

15. Calculated average of two bulk samples ("Type A and B") from the Juan de Fuca Ridge (Bischoff et al., 1983).

16. Calculated average of two "polymetallic sulfide (inner and middle chimney walls) samples" from the Escabana Trough, South Gorda Ridge (Benninger and Koski, 1987)

17. One sample of the outer chimney wall from the same locality as 16 (Benninger and Koski, 1987).

*All element contents in ppm except the majors marked $*$ which are in $\% ;$ n.d. $=$ not detected $-=$ not analyzed.

composition is close to the composite massive sulfide from the EPR at $21^{\circ} 5^{\prime} \mathrm{S}$ (Table 2, column 9). It is also similar to a calculated average composition for the TAG hydrothermal field, using the analyses given in Table 2, columns $2-4: \mathrm{Fe}=$ $27.8 \% ; \mathrm{Zn}=7.2 \% ; \mathrm{Cu}=11.7 \% ; \mathrm{S}=39.5 \%$. By their relatively high copper contents, the average compositions of sulfides from the Galapagos Spreading Center are also similar (Table 2, columns 10-11), but these only contain traces of zinc. All these samples are characterized by the abundance of pyrite (or pyrrhotite in the case of the Snake Pit samples) and minor marcasite as the major constituents, along with $\mathrm{Cu}, \mathrm{Fe}$ sulfides. The amount of $\mathrm{Cu}$ in the Snake Pit bulk samples (12\% average) falls between that of the representative samples from the EPR at $21^{\circ} \mathrm{S}(6.8 \% \mathrm{Cu})$ or the Galapagos Spreading Center $(6.5 \% \mathrm{Cu})$ and that of inner layer of a chimney from the TAG $(33.37 \% \mathrm{Cu})$. This high copper content reflects high temperature crystallization.

On the other hand, the average mound sample from the Snake Pit area has a quite different chemical composition than the $\mathrm{Zn}$-rich bulk samples from the EPR at $21^{\circ} \mathrm{N}$ (Table 2, columns 5-8) or the Juan de Fuca Ridge (Table 2, columns 13-15). Zn content of the Galapagos massive sulfide is low $(0.1 \%-1 \%)$, whereas, in Snake Pit and the $21^{\circ} 5^{\prime}$ S EPR mate- rials, sphalerite is responsible for the $6.7 \%$ and $9.1 \% \mathrm{Zn}$, respectively.

The silica content of the ocean floor massive sulfides is extremely variable from sample to sample, ranging from $0.5 \%$ or less to $19 \%$ for the EPR sulfides (Bischoff et al., 1983; Zierenberg et al., 1984) or from $0.2 \%$ to $19.3 \%$ for TAG sulfides (Thompson et al., 1988).

\section{Trace elements}

The Snake Pit bulk samples have a high Au content with a $600 \mathrm{ppb}$ average (see Table 1). Au content is generally much lower in unaltered sulfide deposits from the ocean floor (see Table 2). Hekinian et al. (1980) reported high Au concentrations, up to $3.15 \%$ (and $\mathrm{Pt}$ up to $1.17 \%$ ), on the basis of electron microprobe analyses of pyrites and marcasites from the EPR at $21^{\circ} \mathrm{N}$ however, these observations have not been verified by other workers.

Hannington et al. $(1986,1988)$ found exceptional enrichments of Au in hydrothermal sulfide samples from the Southern Explorer Ridge, the Axial Seamount of the Juan de Fuca Ridge, and the TAG area of the MAR. Both the Explorer and the Juan de Fuca Ridges are intermediate-spreading ridges with spreading rates of about $3 \mathrm{~cm} / \mathrm{yr}$ (half-spreading rate). On 
Table 3. Mineralogical associations in the studied samples.

\begin{tabular}{|c|c|c|c|c|}
\hline & sample type & sample \# & \multicolumn{2}{|c|}{ mineral phases } \\
\hline & $\begin{array}{c}\text { type 1 } \\
\text { (po-"rich") }\end{array}$ & 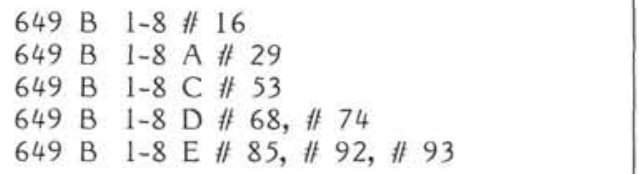 & $\begin{array}{l}\text { po, cub } \\
\text { cp, py, sl }\end{array}$ & $\begin{array}{l}\text { mc, alt.po } \\
\text { sulfates }\end{array}$ \\
\hline $\begin{array}{l}\text { O } \\
\text { L } \\
\text { E }\end{array}$ & $\begin{array}{c}\text { type } 2 \\
\text { (Fe, Cu } \\
\text { sulfides rich) }\end{array}$ & $\begin{array}{l}649 \text { B } 1-8 \text { \# } 21 \\
649 \text { B } 1-8 \text { C \# } 34 \text {, \# } 49 \text {, \# } 54 \\
649 \text { B } 1-8 \text { D \# } 64, \text { \# } 67, \text { \# } 69 \text {, \# } 71 \text {, \# } 73 \\
649 \text { B } 1-8 \text { E \# } 84 \text {, \# } 84 \text {, \# } 90 \\
649 \text { B } 1-8 \text { C \# } 34 \\
649 \text { B } 1-8 \text { C \# } 51 \text {, \# } 52 \\
649 \text { B } 1-8 \text { D \# } 66\end{array}$ & $\begin{array}{l}\text { cub, cp } \\
\text { cub, cp } \\
\text { cub, cp }\end{array}$ & $\begin{array}{c}\text { sl, alt.po, mc } \\
\text { bornite-like phase } \\
\qquad \mathrm{cv} \\
\text { alt.po, mc }\end{array}$ \\
\hline B & type 3 & 649 B $1-8$ \# 17 & sl & cub, cp, alt.po, silica \\
\hline & soft samples & & talc & unidentified sulfides \\
\hline $\begin{array}{c}\text { HOLES } \\
649 \mathrm{~B}\end{array}$ & $\begin{array}{c}\text { type } 2 \\
\text { "massive pieces" }\end{array}$ & $\begin{array}{l}649 \mathrm{G} \quad 1-1 \text { \# } 95 \text {, \#\# } 96 \text {, \# } 98 \text { and } \\
649 \mathrm{~F}\end{array}$ & cub, cp & py, po \\
\hline $\mathrm{F}$ & soft sample & 649 B $1-1$ \#\# 97 & talc & cp, cub, py \\
\hline
\end{tabular}

Abbreviations $: c u b=$ cubic cubanite,$c p=$ chalcopyrite,$p y=$ pyrite, $m c=$ marcasite, $s l=s p h a l e r i t e, c v=c o v e l l i t e$

the other hand, in the TAG region, the Mid-Atlantic Ridge spreads at the half rate of $1.3 \mathrm{~cm} / \mathrm{yr}$. At all three locales, Au-rich samples come from "mature" sulfide mounds whose characteristics could also apply to the Snake Pit area: "the steep sided mounds of massive sulfides up to $10 \mathrm{~m}$ thick $(50 \mathrm{~m}$ height at the TAG) and $20 \mathrm{~m}$ or more in diameter ( 220 by 250 $\mathrm{m}$ across at the TAG) are capped by large chimney-like structures . . . which can reach heights of more than $10 \mathrm{~m}$." Moreover, it is said that both high-temperature vents $\left(>300^{\circ} \mathrm{C}\right)$ may exit from the chimneys on top of the mounds, "but a large proportion of the hydrothermal activity consists of diffuse, lower temperature $\left(<250^{\circ} \mathrm{C}\right)$ venting." These observations are also similar to those made at the Snake Pit hydrothermal field where high-temperature solutions $\left(330^{\circ}-\right.$ $350^{\circ} \mathrm{C}$ ) exit from $>11$-m-high chimneys whereas low-temperature $\left(225^{\circ} \mathrm{C}\right)$ diffuse fluids ooze through the pedestal of these chimneys (Thompson et al., 1988; Mével et al., 1989).

In the sulfides from the Axial Seamount and the Southern Explorer Ridge, Au seems to be associated with late precipitates such as sphalerite, Ag-bearing $\mathrm{Pb}$ - $\mathrm{As}$-Sb sulfosalts, and amorphous silica (Hannington et al., 1986). At the TAG, free grains of Au up to $15 \mu \mathrm{m}$ in diameter occur with fine grained digenite at the margin of altered chalcopyrite in secondary sulfides such as covellite and bornite associated with corroded pyrite, amorphous silica, native copper, Fe-oxides, and atacamite (Hannington et al., 1988).

Average Au content of primary $\mathrm{Zn}-\mathrm{Fe}-\mathrm{Cu}$ sulfides from the TAG is $2400 \mathrm{ppb}$ whereas it is $11,200 \mathrm{ppb}$ in the secondary sulfides. Au content averages $4900 \mathrm{ppb}$ and $660 \mathrm{ppb}$ in the samples from the Axial Seamount and the Southern Explorer
Ridge, respectively. Hannington et al. (1986) explain such high content by means of Au remobilization and reconcentration during multistage growth of mature sulfide mounds. Sustained diffusion of low-temperature $\left(<250^{\circ} \mathrm{C}\right)$ hydrothermal fluids can remove $\mathrm{Au}$ as bisulfide complexes from the background level of $\mathrm{Au}$ in high-temperature sulfides and reconcentrate it in the cooler outer portions of the mounds. According to Hannington et al. (1986) such a process, rather similar to the "zone refining process"' suggested by Hekinian and Fouquet (1985) for the East Pacific Rise at $13^{\circ} \mathrm{N}$, could enrich $\mathrm{Au}$ by at least one order of magnitude above the $\mathrm{Au}$ background level of $200 \mathrm{ppb}$.

On the other hand, the sulfide samples from "immature" sulfide mounds of other hydrothermal fields in the Pacific only contains $<200 \mathrm{ppb}$ background Au content (see Table 2) with the exception of one of the Galapagos Spreading Center massive sulfides. Even though this deposit is grouped with the "immature mounds" by Hannington et al. (1986), its description by Malahoff (1982) clearly indicates that it is a mature sulfide deposit: "the largest deposit mapped consists of coalesced inactive chimneys $35 \mathrm{~m}$ high . . . extending over a width of between 20 and $200 \mathrm{~m}$ and extending for a length of perhaps $1000 \mathrm{~m}$." The composite sample made up of seven fragments (see above) is said to have an average Au content of less than 2 ppm (Malahoff, 1982; see Table 2, column 11) and a single sample from the same mound contained $0.05 \mathrm{ppm}$ of $\mathrm{Au}$ (Bischoff et al., 1983; Table 2, column 10). The sample from Alvin station N-1128-2D on top of the mound gave a $0.32 \mathrm{ppm}$ Au content (Table 2, column 12 , this study). 


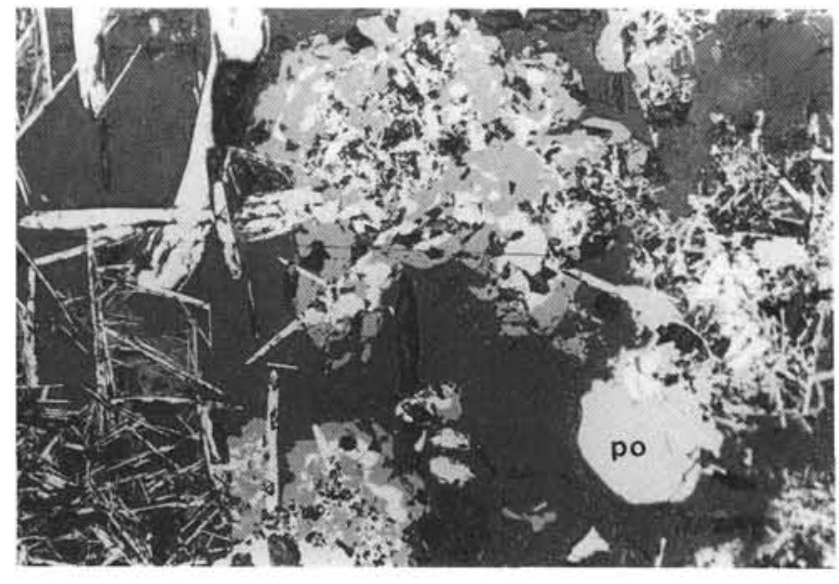

Figure 3. Photomicrograph in reflected light of a polished section showing typical texture of type I samples (649B-1D-8C, \#53). "Cockade"-like intergrowths of sphalerite and $\mathrm{Cu}, \mathrm{Fe}$ sulfides are isolated by clusters of pyrrhotite tablets. A beautiful hexagonal crystal of pyrrhotite (po) is also visible. Scale bar $=100 \mu \mathrm{m}$.

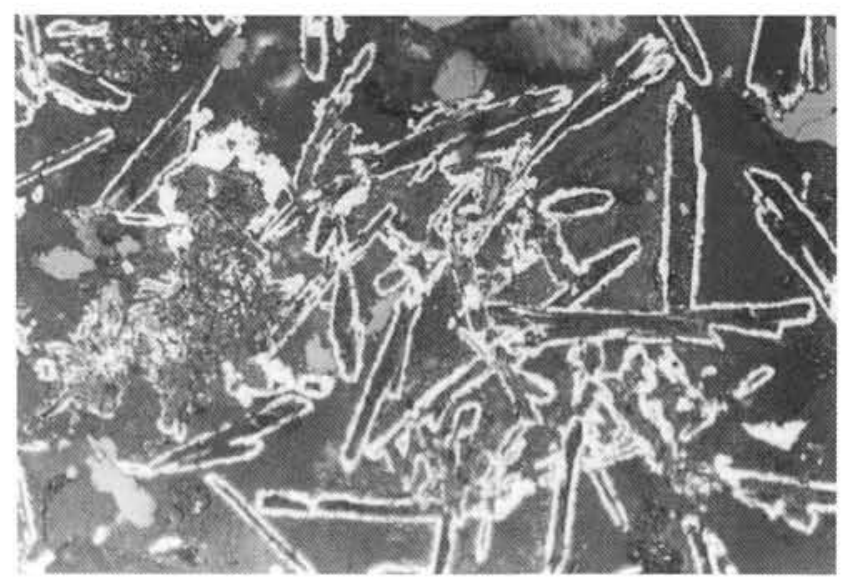

Figure 4. Photomicrograph in reflected light of a polished section of a type 1 sample (649B-1D-8, \#16). Skeletal pseudomorphs after pyrrhotite tablets replaced by pyrite and sulfates. Scale bar $=50 \mu \mathrm{m}$.

According to Hannington et al. (1986), the "immature sulfide mounds" are common on medium- and fast-spreading ridges of the East Pacific Rise, and, hence, such low Au level would be characteristic of young sulfide deposits lacking the sustained hydrothermal activity responsible for the reconcentration of Au accompanying the precipitation of late secondary sulfides, sulfosalts, and amorphous silica.

The average $178 \mathrm{ppm}$ Se content of the bulk sample from Hole 649B is within the $90-360$ ppm range of Se content of the Galapagos Spreading Center analyses (Table 2, columns 1012). This Se content is much lower than that of chalcopyriterich walls, especially their inner portions, of active chimneys whose Se contents range from 400 to $950 \mathrm{ppm}$ in the Escabana Trough of Gorda Ridge (Benninger and Koski, 1987) or from $645 \pm 150 \mathrm{ppm}$ to $1375 \pm 300 \mathrm{ppm}$ mean Se content in the chimney of the East Pacific Rise at $13^{\circ} \mathrm{N}$ (Auclair et al., 1987). According to the latter authors, the highest Se contents are found in high-temperature assemblages of chalcopyrite (about $2500 \mathrm{ppm}$ ) and pyrite (about $1500 \mathrm{ppm}$ ).

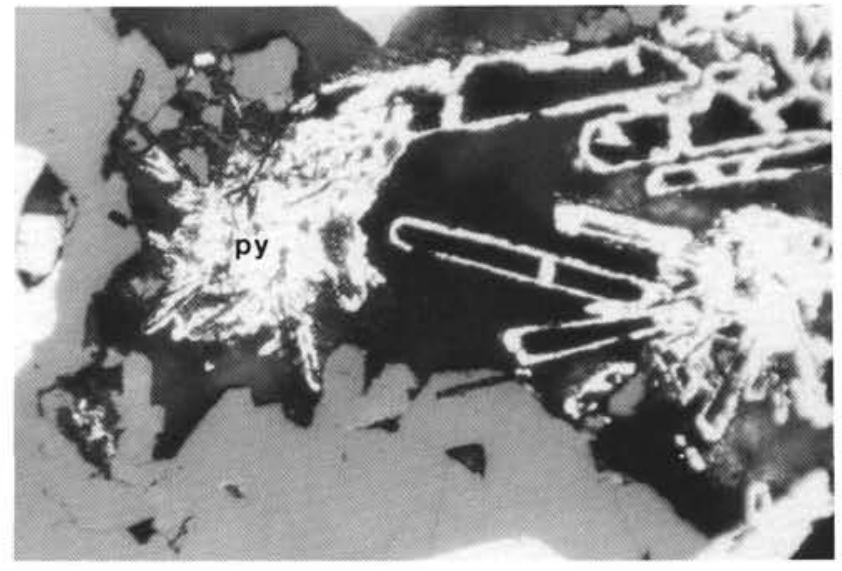

Figure 5. Photomicrograph in reflected light of a polished section of a type 1 sample (649B-1D-8A, \#16). Masses of second generation pyrite (py) and pyrrhotite tablets altered to pyrite occur between sphalerite grains. Scale bar $=25 \mu \mathrm{m}$.

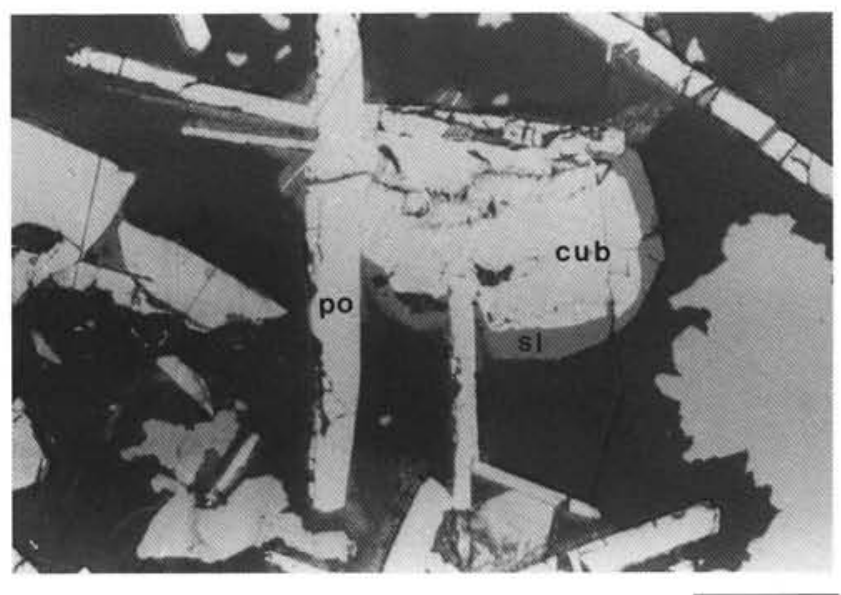

Figure 6. Photomicrograph in reflected light of a polished section of a type 1 sample (649B-1-8, \#53). Tablets of fresh pyrrhotite (po) are partially enclosed in intergrown chalcopyrite and cubic cubanite (cub), rimmed by sphalerite (sl). Scale bar $=40 \mu \mathrm{m}$.

\section{MINERALOGY}

\section{Analytical methods}

A large number of sulfide fragments were selected for mineralogical studies: the bulk compositions discussed above correspond to a mixture of these fragments. Mineral phases were first identified by reflected light microscopy, in 30 polished sections. The determination was eventually completed by XRD and SEM. Minerals were analyzed with CAMECA microprobes at three different laboratories: in CAMPARIS, Université P. et M. Curie, Paris, Microsonde de l'Ouest, Brest (analyst, C. Mével), and Centre de Recherches Pétrographiques et Géochimiques du CNRS, Nancy (analyst, J. Honnorez). Analytical conditions: accelerating voltage $=15 \mathrm{kV}$, beam current $=40 \mathrm{~mA}$, counting time $=10 \mathrm{~s}$ for major elements and $=20 \mathrm{~s}$ for trace elements. Debye-Scherrer X-ray powder diffraction camera was used with $\mathrm{Co}-\mathrm{K}$ radiation and Fe-filter at $100 \mathrm{kV}$ and $10 \mathrm{~mA}$ to identify pyrrhotite varieties.

\section{Mineralogical assemblages and textures}

Preliminary determination by X-ray diffraction on board the JOIDES Resolution had shown that sulfide deposit con- 


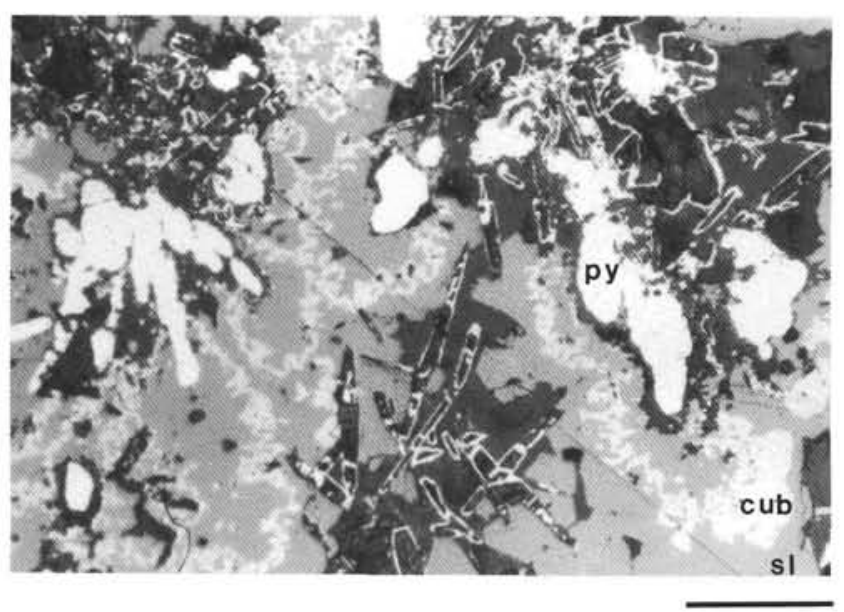

Figure 7. Photomicrograph in reflected light of a polished section of a type 1 sample (649B-ID-8, \#16). First generation pyrite (py) is corroded and enclosed in sphalerite (sl) with a $\mathrm{Cu}, \mathrm{Fe}$ sulfide layer (cub). Skeletal pyrrhotite tablets (po) are altered to pyrite. Scale bar $=100 \mu \mathrm{m}$.

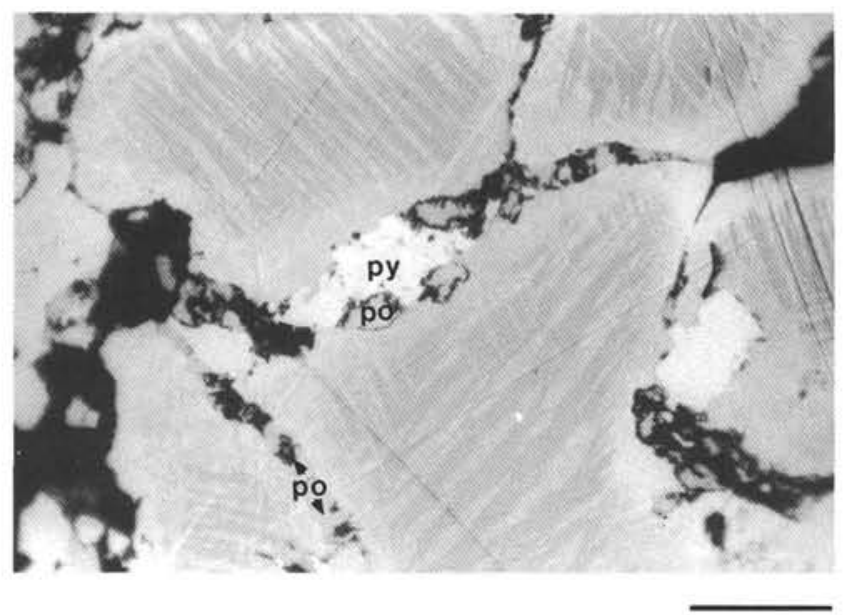

Figure 8. Photomicrograph in reflected light of a polished section of a type 2 sample (649G-1D-1, \#96). Cu, Fe sulfide grains showing lamellae of chalcopyrite (light gray) in cubic cubanite (dark gray), rimmed by chalcopyrite. Grains of pyrite (py) and veinlets of pyrrhotite (po) along boundaries of coarse $\mathrm{Cu}, \mathrm{Fe}$ sulfide grains. Scale bar = $50 \mu \mathrm{m}$.

sists mainly of $\mathrm{Cu}, \mathrm{Fe}$ sulfides, sphalerite, pyrrhotite, pyrite, and marcasite. This observation was confirmed by the present, more detailed study and only a few minor phases were subsequently identified.

Besides the talc-rich sample, three types of sulfide assemblages have been recognized among all the samples studied: pyrrhotite-rich (type 1), $\mathrm{Cu}, \mathrm{Fe}$ sulfide-rich (type 2), and sphalerite-rich (type 3 ) (Table 3 ). Type 1 and type 3 samples are porous and their grain size is small, i.e., $<200 \mu \mathrm{m}$ in diameter. On the other hand, type 2 samples are massive, coarse to medium grained, up to $300 \mu \mathrm{m}$ in size.

Type 1. The pyrrhotite-rich samples are either made up of unaltered tablets of pyrrhotite (Samples 649B-1D-8C, \#53, Fig. 3 ; 649B-1D-8E, \#84) or more often of altered pyrrhotite tablets (Sample 649B-1D-8, \#16, Figs. 4 and 5; Sample 649B-1D-8A, \#29; Sample 649B-1D-8E, \#85, and others). $\mathrm{Cu}, \mathrm{Fe}$ sulfides and sphalerite are approximately as abundant as tablets of unaltered and/or altered pyrrhotite.

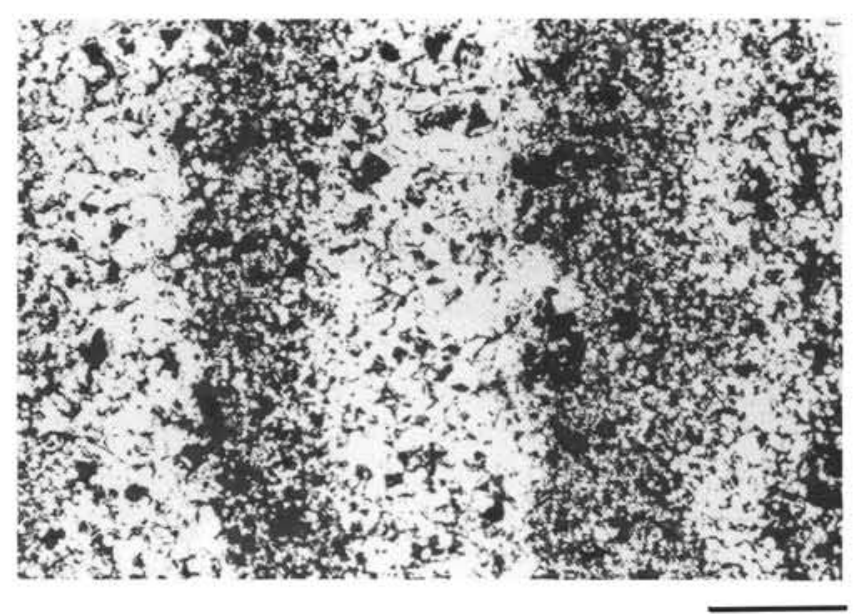

Figure 9. Photomicrograph in reflected light of a polished section of a type 2 sample (649B-ID-8C, \#54). Layering in a tube fragment corresponding to a variation in grain size of the $\mathrm{Cu}, \mathrm{Fe}$ sulfides.

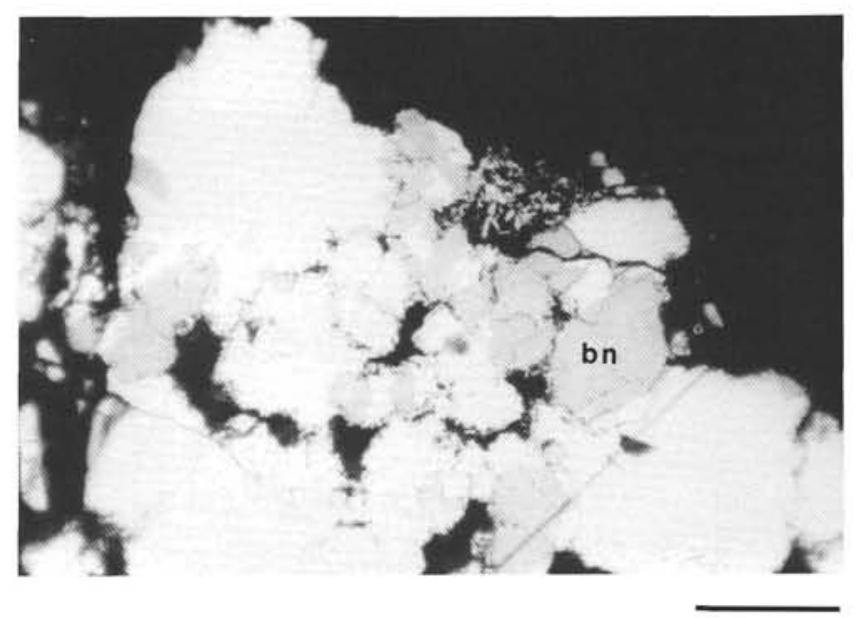

Figure 10. Photomicrograph of a polished section of a type 2 sample (649B-1-8C, \#54). Bornite-like mineral (bn), replacing chalcopyrite (light gray). Scale bar $=130 \mu \mathrm{m}$.

The unaltered pyrrhotite tablets, up to $200 \mu \mathrm{m}$ in length, are generally scattered through the samples. They are partly enclosed in the sphalerite/Fe, Cu sulfide assemblages (Fig. 6) and protrude in voids between these phases. Unidentified sulfate pseudomorphs after the pyrrhotite tablets can be rimmed by pyrite (Fig. 4). Clusters of anhedral, fine grained, later generation pyrite are attached to the pyrrhotite pseudomorphs (e.g., Sample 649B-1D-8A, \# 16, Fig. 5). In several samples (649B-1D-8A, \#29, 649B-1D-8E, \#85), however, the pyrrhotite tablets are completely replaced by a fine pyritemarcasite aggregate similar to Ramdhor's "intermediate product" (1969, p. 594).

A magnetic colloidal solution (Scott, 1974) was used to test whether pyrrhotite is hexagonal (nonmagnetic) or monoclinic (magnetic). The solution was unevenly attracted by the unaltered pyrrhotite tablets in Samples 649B-1D-8C, \#53, and 649B-1D-8D, \#71. Hence, we tentatively infer that the tablets are, at least partly, formed by monoclinic pyrrhotite. DebyeScherrer X-ray diffraction films were unhelpful in asserting whether the tablets of these samples are hexagonal pyrrhotite (single 102 X-ray peak) or monoclinic (408-408 doublet) after Kissin (in Scott, 1974). The uncertainty is due to the scarcity 


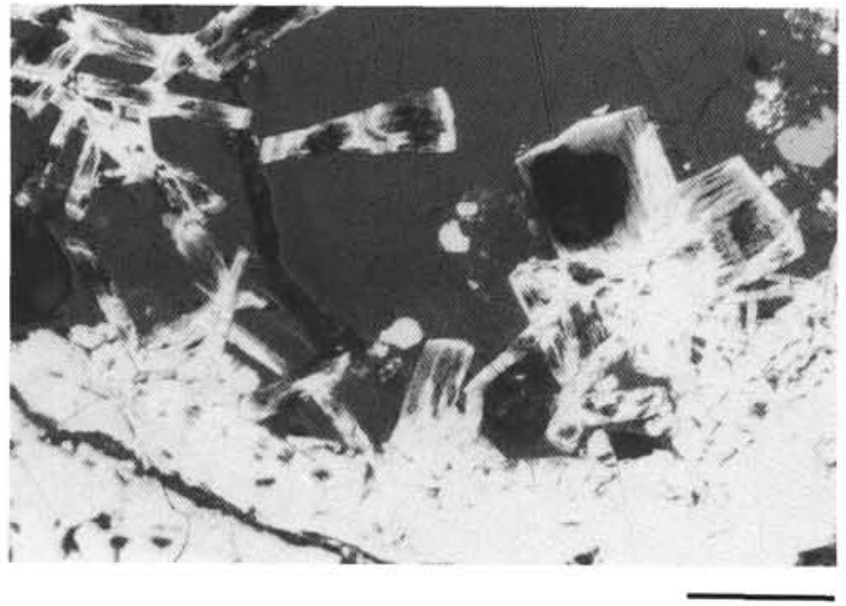

Figure 11. Photomicrograph of a polished section of a type 2 sample (649B-1D-8D, \#68). Altered pyrrhotite on the edge of a chalcopyrite/ cubic cubanite intergrowth. Scale bar $=50 \mu \mathrm{m}$.

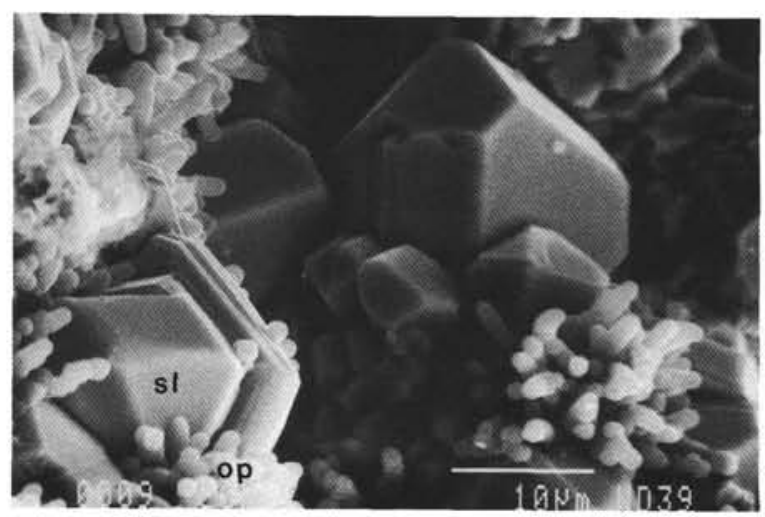

Figure 12. Scanning electron microscope photomicrograph showing opal spherules (op) on automorph sphalerite crystals (sl), Sample 649B-1-8, \#97. Scale bar $=10 \mu \mathrm{m}$.

of the powdered material sampled under the microscope and the presence of traces of other sulfide phases.

An early generation of pyrite is common in this type of sample where it forms corroded crystals, up to $200 \mu \mathrm{m}$ across, commonly surrounded by sphalerite or sphalerite/chalcopyrite intergrowths forming a cockade texture (e.g., Sample 649B1D-8, \#16, Fig. 7).

Type 2 . The $\mathrm{Cu}, \mathrm{Fe}$ sulfide-rich samples are mostly made up massive granular aggregates of anhedral cubic cubanite grains, up to $300 \mu \mathrm{m}$ across, with lamellae and rims of chalcopyrite (e.g., Sample 649G-1D-1, \#96, Fig. 8). Such a relationship suggests an exsolution of chalcopyrite lamellae in the center of cubic cubanite grains, and a replacement of the latter phase by chalcopyrite at the grain rims. The $\mathrm{Cu}, \mathrm{Fe}$ sulfides sometimes enclose euhedral pyrite crystals. Veinlets of pyrrhotite are common in the interstices within the $\mathrm{Cu}, \mathrm{Fe}$ sulfide granular aggregates (e.g., Sample 649G-1D-1, \#96, Fig. 8). Abundant anhedral pyrite occupies positions between the $\mathrm{Cu}, \mathrm{Fe}$ sulfide grains and become euhedral when protruding into intergranular voids. Finally anhedral marcasite is sometimes located between the $\mathrm{Cu}, \mathrm{Fe}$ sulfide grains and the pyrrhotite veins. The magnetic colloidal solution was clearly attracted by the pyrrhotite veinlets of Sample 649G-1D-1,

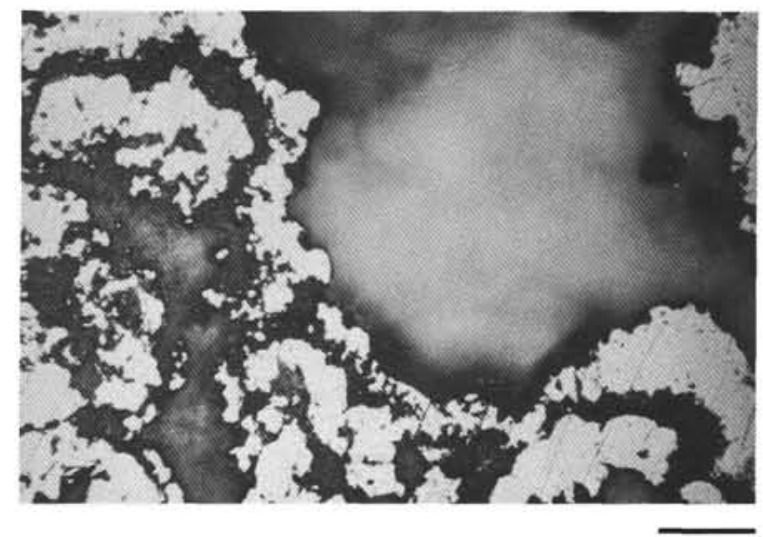

Figure 13. Polished section photomicrograph of Sample 649G-1D-1, $23-26 \mathrm{~cm}$, illustrating the recurrent chalcopyrite (white)-talc (gray) concentric botryoidal texture. The large milky field in the upper right quarter is plastic. Scale bar $=30 \mu \mathrm{m}$.

Table 4. Representative analyses of pyrrhotite (As, Ni, Sb, and Se contents are below detection limits; nd = not detected).

\begin{tabular}{|c|c|c|c|c|c|c|}
\hline \multirow{4}{*}{$\begin{array}{l}\text { sample } \\
\mathrm{N}^{\circ} \\
\text { wt } \%\end{array}$} & \multicolumn{3}{|c|}{ type 1} & \multicolumn{3}{|c|}{ type 2} \\
\hline & \multirow{3}{*}{$\begin{array}{c}\text { 649B 1-8 E } \\
93 \\
\text { Tablets }\end{array}$} & \multicolumn{2}{|c|}{$649 \mathrm{~B} 1-8 \mathrm{C}$} & \multirow{3}{*}{$\begin{array}{c}\text { 649G 1-1 } \\
96 \\
\text { Veinlets }\end{array}$} & \multicolumn{2}{|c|}{$649 \mathrm{~B} \quad 1-8 \mathrm{E}$} \\
\hline & & 53 & 53 & & 84 & 84 \\
\hline & & \multicolumn{2}{|c|}{ Tablets } & & \multicolumn{2}{|c|}{ Tablets } \\
\hline $\mathrm{S}$ & 39.38 & 38.57 & 39.70 & 39.90 & 40.39 & 40.03 \\
\hline $\mathrm{Fe}$ & 60.64 & 61.46 & 60.07 & 57.69 & 60.22 & 59.46 \\
\hline $\mathrm{Cu}$ & 0.01 & nd & 0.01 & 0.81 & nd & nd \\
\hline Zn & 0.07 & 0.01 & 0.17 & 0.04 & nd & nd \\
\hline Cd & nd & nd & nd & 0.05 & 0.02 & 0.02 \\
\hline Co & 0.17 & nd & nd & 0.24 & 0.07 & nd \\
\hline Total & 100.27 & 100.04 & 99.95 & 98.73 & 100.76 & 99.64 \\
\hline at $\%$ & & & & & & \\
\hline S & 52.99 & 52.22 & 53.45 & 54.22 & 53.82 & 53.92 \\
\hline $\mathrm{Fe}$ & 46.84 & 47.77 & 46.43 & 45.00 & 46.08 & 45.99 \\
\hline $\mathrm{Cu}$ & 0.01 & nd & 0.01 & 0.56 & nd & nd \\
\hline $\mathrm{Zn}$ & 0.05 & 0.01 & 0.11 & 0.03 & nd & nd \\
\hline Cd & nd & nd & nd & 0.02 & 0.01 & 0.01 \\
\hline Co & 0.12 & nd & nd & 0.18 & 0.05 & nd \\
\hline
\end{tabular}

\#92, and we can therefore infer that this pyrrhotite is monoclinic.

Sample 649B-1D-8C, \#54 (Fig. 9), displays a layering due to variation in grain size of the $\mathrm{Cu}, \mathrm{Fe}$ sulfide grains.

Sample 649B-1D-8C, \#34, is a fragment of a 1-cm outer diameter tube. The $\mathrm{Cu}, \mathrm{Fe}$ sulfide displays radial texture from the inner to the outer walls of the tube. The coarse elongated grains of cubic cubanite/chalcopyrite forming the inner part of the tube decrease in size and change to chalcopyrite toward the outer wall. (Both samples display late covellite, a mineral optically like bornite (Fig. 10), and pyrrhotite tablets at the periphery.)

In Samples 649B-1D-8C, \#53, -1D-8D, \#68, and -1D-8, \#71, $\mathrm{Cu}, \mathrm{Fe}$ sulfides are rimmed by sphalerite. Unaltered or altered pyrrhotite tablets (Fig. 11) occur in the spaces between the grains of $\mathrm{Cu}, \mathrm{Fe}$, or $\mathrm{Zn}$ sulfides. 


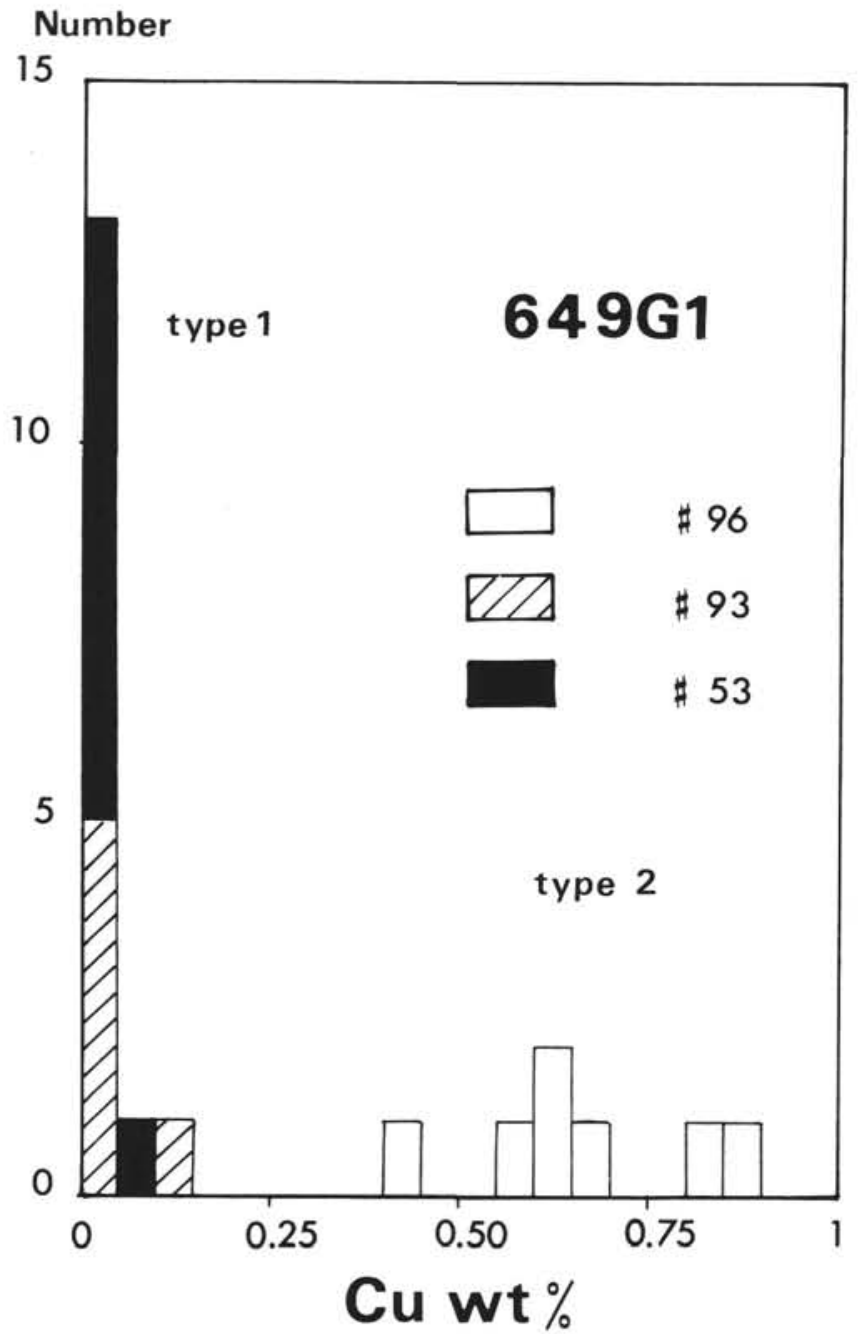

Figure 14. Histogram of $\mathrm{Cu}$ content in wt\% in pyrrhotite from type 1 and type 2 samples.

From these observations, it is inferred that $\mathrm{Cu}, \mathrm{Fe}$ sulfides precipitate early, possibly after a first generation of pyrite. Then sphalerite, chalcopyrite, and/or pyrrhotite form. Late pyrite and marcasite may be also present. The late supergene alteration products of $\mathrm{Cu}, \mathrm{Fe}$ sulfides are scarce.

Type 3. Sphalerite-rich sample (649B-1D-8, \#17) mainly consists of zoned sphalerite crystals, about $100 \mu \mathrm{m}$ in diameter. In thin section, the sphalerite grains are generally opaque in the center and transparent at the margin. A few anhedral grains of $\mathrm{Cu}, \mathrm{Fe}$ sulfides and altered pyrrhotite tablets occur scattered among the sphalerite grains. Rare late sphalerite also o ccurs as overgrowths on sphalerite. SEM photographs (Fig. 12) illustrate the morphology of the sphalerite crystals and the occurrence of interstitial amorphous silica spherules.

The talc-rich sample. In Sample 649G-1D-1, 23-26 cm, chalcopyrite and talc alternate to form a concentric botryoidal texture (Fig. 13). Cubic cubanite grains with chalcopyrite lamellae are rare, and they seem corroded along contact with the surrounding talc. Small anhedral and subhedral pyrite grains are also occasionally associated with the $\mathrm{Cu}, \mathrm{Fe}$ sulfides. Microprobe analyses of this sample were not reliable because of the bad polish resulting from the contrasted hardness of the talc-sulfide mixture in thin polished section and polished slab. Semiquantitative energy-dispersive analy- ses with an EDS-equipped SEM indicate that the talc only contains $\mathrm{Mg}$ and $\mathrm{Si}$; Fe content is below detection limit.

\section{Mineral chemistry}

Sulfides were analyzed for $\mathrm{S}, \mathrm{Fe}, \mathrm{Zn}, \mathrm{Cu}, \mathrm{Cd}, \mathrm{Co}$, and $\mathrm{Ni}$, and $\mathrm{As}, \mathrm{Se}, \mathrm{Sb}$, and $\mathrm{Pb}$ in a few samples. Nickel, antimony, and lead are always below detection limit in all of the minerals analyzed.

\section{Pyrrhotite}

The two types of pyrrhotite, tablets and veinlets, have different chemical compositions. In pyrrhotite-rich samples (type 1), tablets of pyrrhotite are a major phase. They are nearly pure, and contain traces of $\mathrm{Cu}, \mathrm{Zn}$, and $\mathrm{Co}$ (Table 4). In the massive $\mathrm{Cu}, \mathrm{Fe}$ sulfide-rich samples (type 2) from Hole $649 \mathrm{G}$, granular veinlets of pyrrhotite contain up to $0.8 \mathrm{wt} \%$ $\mathrm{Cu}, 0.24 \mathrm{wt} \% \mathrm{Co}$, and traces of $\mathrm{Zn}$ and $\mathrm{Cd}$. The difference between the two types of pyrrhotite is well illustrated in a $\mathrm{Cu}$ histogram (Fig. 14).

\section{Pyrite and marcasite}

In Samples 649B-1D-8, \#16, mineral chemistry confirms the textural evidence about the presence of at least two generations of pyrite in type 1 samples. The first generation of pyrite associated with sphalerite contains abundant zinc (up to $4.5 \mathrm{wt} \%$, Table 5). In the same sample, second generation pyrite has lower zinc content $(0.88$ wt $\%$, Fig. 15 , Table 5$)$. High $\mathrm{Zn}$ contents in pyrites from the EPR have been attributed to submicroscopic inclusions of $\mathrm{ZnS}$ (Zierenberg et al., 1984). It could be also the case in this samples. In all of the other samples, the zinc content of pyrites is extremely low (Table 5). The Co content of pyrite varies in optically zoned crystals. Zoned pyrite is associated with coarse grained anhedral cubic cubanite in the massive sulfide Samples 649G-1D-1, 14-16 cm, \#95, and \#96. The lighter cores and rims of pyrite contain only small amounts of Co (around $0.15 \mathrm{wt} \%$ ) whereas Co content of the darker intermediate bands ranges from 0.30 to $0.43 \mathrm{wt} \%$ (Table 5). The $\mathrm{Cu}$ content of the zoned pyrite ranges from below detection limit to $0.11 \mathrm{wt} \%$ but these variations are not related to Co content.

Marcasite is always very pure, either when well crystallized between $\mathrm{Cu}, \mathrm{Fe}$ sulfide grains and interstitial pyrite in type 2 samples (649G-1D-1, \#95 and \#96) or when forming fine grained aggregates with pyrite as pyrrhotite tablet pseudomorphs in type 1 samples (649B-1D-8, \#16).

\section{$\mathrm{Cu}, \mathrm{Fe}$ Sulfides}

$\mathrm{Cu}, \mathrm{Fe}$ sulfides are major phases in type 2 and less abundant in type 1 samples. Chalcopyrite forms exsolution lamellae within, and rims around, cubic cubanite. Composition of both phases are not easy to determine because the exsolution lamellae are often very small $(<2 \mu \mathrm{m})$. Therefore, the microprobe analyses might correspond to a mixture of the two phases. Analyses of the two phases have nevertheless been carried out in type 1 (pyrrhotite-rich) and type $2(\mathrm{Cu}, \mathrm{Fe}$ sulfide-rich) samples. Compositions of both phases are very similar for the two types of samples as shown in a $\mathrm{Fe}-\mathrm{Cu}-\mathrm{S}$ triangle (Fig. 16). Chalcopyrite plots close to pure chalcopyrite but with a shift toward Fe-enriched compositions. Cubic cubanite plots in or near the ISS field 1 of Cabri (1973). It is impossible to determine what the composition of the original phase was, but it was likely in ISS field 1 as already suggested for other oceanic sulfide deposits (Zierenberg et al., 1984). The composition scattering is probably due in part to analytical problems (see above) and does not permit defining an evolution of the $\mathrm{Cu}, \mathrm{Fe}$ sulfide phases with time. 


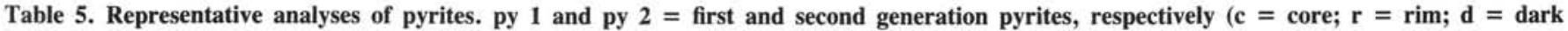
intermediate band; $\mathrm{nd}=$ not detected). ${ }^{*}=\mathrm{As}, \mathrm{Ni}, \mathrm{Sb}$, and $\mathrm{Se}$ contents are below detection limits.

\begin{tabular}{|c|c|c|c|c|c|c|c|c|c|c|c|c|c|}
\hline \multirow[b]{4}{*}{ wt \% } & \multicolumn{6}{|c|}{ type 1} & \multicolumn{7}{|c|}{ type 2} \\
\hline & \multicolumn{5}{|c|}{$649 B 1-8 \# 16$} & \multirow{3}{*}{\begin{tabular}{|c|} 
649B 1-8 C \#53 \\
py 1
\end{tabular}} & \multicolumn{2}{|c|}{$649 \mathrm{G} 1-1 \# 96$} & \multirow{3}{*}{$\begin{array}{c}* 649 B 1-8 \text { E \# } 84 \\
p y 2 \\
\end{array}$} & \multirow{2}{*}{\multicolumn{4}{|c|}{$\begin{array}{c}* 649 \mathrm{G} 1-1 \| 95 \\
\text { py } 1\end{array}$}} \\
\hline & \multicolumn{2}{|c|}{ py 1} & py 1 & \multicolumn{2}{|c|}{ py 2} & & \multirow[t]{2}{*}{ py 1} & \multirow[t]{2}{*}{ py 2} & & & & & \\
\hline & c & $\mathbf{r}$ & c & & & & & & & c & $r$ & d & d \\
\hline$S$ & 51.24 & 52.52 & 52.38 & 52.52 & 52.51 & 53.33 & 53.59 & 53.26 & 54.41 & 52.88 & 52.73 & 53.08 & 52.39 \\
\hline $\mathrm{Fe}$ & 43.48 & 44.34 & 45.82 & 45.91 & 46.26 & 47.13 & 46.13 & 45.70 & 46.30 & 46.04 & 45.30 & 46.24 & 45.47 \\
\hline $\mathrm{Cu}$ & nd & nd & nd & nd & 0.10 & nd & 0.39 & 0.82 & 0.03 & 0.02 & 0.11 & 0.08 & nd \\
\hline$Z_{n}$ & 4.53 & 2.96 & 1.44 & 0.88 & 0.43 & nd & nd & 0.09 & 0.04 & nd & nd & 0.08 & nd \\
\hline Cd & nd & nd & nd & 0.02 & nd & nd & nd & nd & nd & 0.02 & nd & 0.03 & nd \\
\hline Co & nd & nd & nd & nd & nd & nd & 0.16 & 0.46 & nd & 0.20 & 0.14 & 0.30 & 0.43 \\
\hline $\begin{array}{l}\text { Total } \\
\text { at } \%\end{array}$ & 99.25 & 99.82 & 99.64 & 99.33 & 99.82 & 100.46 & 100.27 & 100.34 & 100.95 & 99.11 & 98.32 & 99.92 & 98.30 \\
\hline $\mathbf{S}$ & 65.34 & 66.13 & 65.93 & 66.22 & 66.00 & 66.34 & 66.69 & 66.40 & 67.09 & 66.59 & 66.83 & 66.41 & 66.54 \\
\hline $\mathrm{Fe}$ & 31.83 & 32.05 & 33.11 & 33.23 & 33.67 & 33.66 & 32.95 & 32.71 & 32.78 & 33.28 & 32.97 & 33.22 & 33.16 \\
\hline $\mathrm{Cu}$ & nd & nd & nd & nd & 0.06 & nd & 0.24 & 0.52 & 0.02 & 0.01 & 0.07 & 0.05 & nd \\
\hline $\mathrm{Zn}$ & 2.83 & 1.83 & 0.89 & 0.54 & 0.26 & nd & nd & 0.06 & 0.02 & nd & nd & 0.05 & nd \\
\hline $\mathrm{Cd}$ & nd & nd & nd & 0.01 & nd & nd & nd & 0.06 & nd & 0.01 & nd & 0.01 & nd \\
\hline Co & nd & nd & nd & nd & nd & nd & 0.11 & 0.31 & nd & 0.10 & 0.10 & 0.20 & 0.29 \\
\hline
\end{tabular}

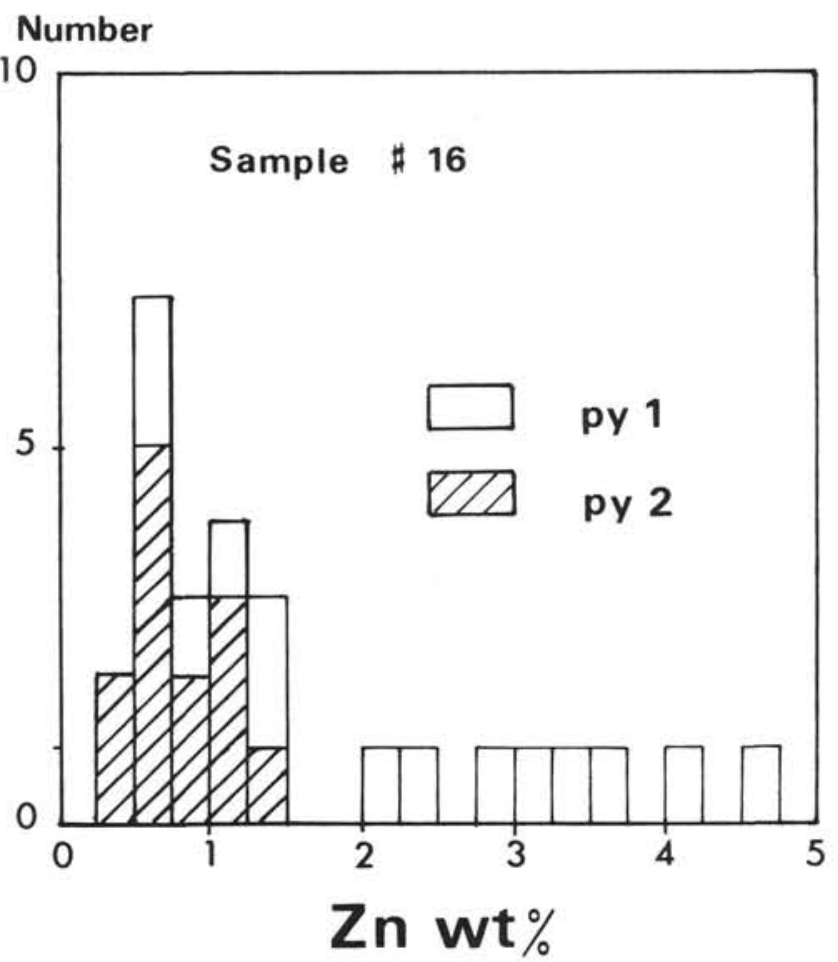

Figure 15. Histogram of $\mathrm{Zn}$ content in wt\% in pyrite from a type 1 sample (649B-1D-8, \#16). py 1 = first generation pyrite, included in sphalerite; py 2 = second generation pyrite.

Minor element contents are somewhat different in the two types of samples. In pyrrhotite-rich type 1 samples, both cubic cubanite and chalcopyrite have high $\mathrm{Zn}$ contents (up to $2 \mathrm{wt} \%$ Table 6, Fig. 17). Zn content is always very low $(<0.3 \mathrm{wt} \%)$ in the other samples. In two type 2 samples $(649 \mathrm{~B}-1 \mathrm{D}-8 \mathrm{D}$, \#68, and 649B-1D-8E, \#90), cubic cubanite contains a little Co (up to $0.3 \mathrm{wt} \%$ ) and always more than the associated chalcopyrite (Fig. 18).
Two alteration phases have been observed in several samples: covellite and a mineral optically like bornite (Table 6). The Fe-Cu-S ternary diagram of Figure 19 shows that the analyzed covellite is similar to the pure end member, but the bornite-like mineral does not correspond to any known phase. Goldfarb et al. (1983) have described an anomalous bornite, but its composition $\left(\mathrm{Cu}_{5} \mathrm{Fe}_{1.05} \mathrm{~S}_{4.42}\right)$ is quite different from that of the mineral analyzed, which is closer to idaite.

\section{Sphalerite}

Sphalerite has an appreciable iron content ranging from 4 to $24 \mathrm{wt} \%$ (Table 7), which replaces $\mathrm{Zn}$ (Fig. 20). The variability of iron behavior in sphalerites is quite striking. In the sphalerite-rich samples, $\mathrm{Zn}$ sulfide crystals show a systematic decrease in iron from center to rim. In the type 2 samples, the iron content is quite variable from crystal to crystal within a single sample. In pyrrhotite-rich samples, the chemical zoning is much more complicated, depending on the nature of the associated phases. For example, three types of sphalerite crystals were analyzed in Sample 649B-1D-8, \#16: (1) with a corroded pyrite core, (2) with a cubic cubanite/ chalcopyrite core, and (3) with a sphalerite core in cockade structures. Figure 21 shows that the $\mathrm{Fe}$ content is quite variable, likely reflecting the varying composition of the hydrothermal fluid from which the sulfides precipitated.

Sphalerites often contain small amounts of cadmium (up to $0.8 \mathrm{wt} \%$ ). Although there is no systematic variation between $\mathrm{Cd}$ and $\mathrm{Fe}$, Figure 22 shows that the highest $\mathrm{Cd}$ concentrations are always found in iron-rich sphalerites. The $\mathrm{Cu}$ content of sphalerites is variable but averages about $0.6 \mathrm{wt} \%$. In the sphalerite-rich samples, zoned crystals show a systematic decrease of $\mathrm{Cu}$ content at the margin, similarly to the iron content decrease.

\section{DISCUSSION}

All of the mineral species found in the Snake Pit hydrothermal mound have been already described in other oceanic hydrothermal fields, with possible exception of the bornitelike mineral. All of the samples display sequential crystalliza- 


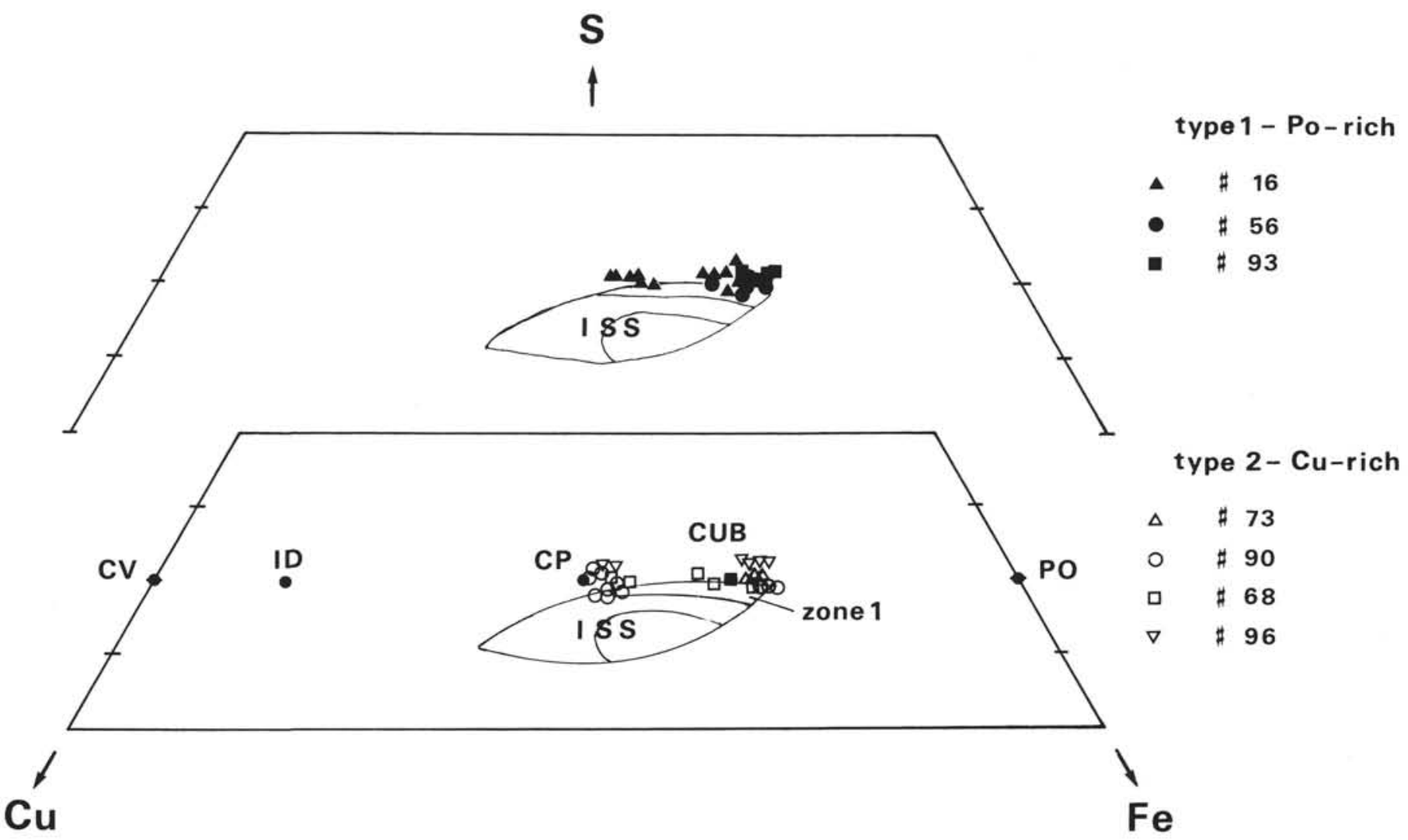

Figure 16. Associated chalcopyrite and cubic cubanite from type 1 and type 2 samples in a portion of the Fe-Cu-S ternary diagram. The field of ISS (after Cabri, 1973) and compositions of chalcopyrite (CP), cubanite (CUB), pyrrhotite (PO), idaite (ID), and covellite (CV) are also shown.

tion of sulfide phases and are characterized by the lack of equilibrium. Precipitation of hydrothermal sulfides on the seafloor essentially results from the mixing of hot, reduced hydrothermal fluids with cold, oxygenated seawater. Many different parameters control the stability of the sulfide species: $\mathrm{pH}$, oxygen and sulfur fugacities, temperature, and the fluid composition are expected to fluctuate widely and influence the paragenetic sequence. The lack of textural relationships between the various types of samples drilled in the hydrothermal mound and the absence of chimney samples make it impossible to reconstruct the evolution of the massive sulfide deposit. This will be done by studying the samples collected by submersible. However, several particularities of the Snake Pit are worth discussing.

The Snake Pit hydrothermal deposit is characterized by the abundance of $\mathrm{Cu}$, Fe sulfides and high $\mathrm{Cu}$ concentrations (12 wt $\%)$. $\mathrm{Cu}, \mathrm{Fe}$ sulfides precipitate at high temperatures, above $250^{\circ} \mathrm{C}$. The study of other oceanic hydrothermal fields has demonstrated that $\mathrm{Fe}, \mathrm{Cu}$ sulfides precipitate during the second stage of activity, after the formation of an outer shell or wall of $\mathrm{Fe}$ and/or $\mathrm{Zn}$ sulfides at lower temperature, preventing the high-temperature hydrothermal fluid from mixing with seawater. $\mathrm{Cu}, \mathrm{Fe}$ sulfides typically form the inner wall of active chimneys with fluids exiting at $350^{\circ} \mathrm{C}$ (Haymon and Kastner, 1981; Goldfarb et al., 1983; Koski et al., 1984; Hekinian and Fouquet, 1985). Type 2 samples, essentially composed of $\mathrm{Cu}$, Fe sulfides, could therefore be fragments of chimneys incorporated into the mound. The high $\mathrm{Cu}$ content of the interstitial pyrrhotite in the massive sulfide block from Hole 649G also supports the idea of high temperature of precipitation (Sugaki et al., 1975). In the sulfides from the Juan de Fuca Ridge, Koski et al. (1984) suggest that the ratio between $\mathrm{Cu}, \mathrm{Fe}$ sulfides and $\mathrm{Zn}$ sulfides in the inner wall could be an indication of the duration of high-temperature venting of $\mathrm{Cu}$-rich fluids at a particular chimney. If this is the case, the abundance of copper suggests that venting of high-temperature $\mathrm{Cu}$-rich fluids is not a short-lived process at the Snake Pit.

Another characteristic of the Snake Pit mound is the relative abundance and freshness of pyrrhotite. Pyrrhotite is abundant in vent particulate matter or black smoke and alters rapidly to pyrite and/or marcasite (Haymon and Kastner, 1981). This alteration may reflect a lowering of the temperature or an increase in oxygen fugacity. The preservation of pyrrhotite suggests either that the deposit is very young or that hightemperature and/or reduced conditions are maintained, possibly by fluids seeping through the mature mound. This hypothesis has been verified by observations from submersible vessels.

The presence of talc repeatedly intergrown with $\mathrm{Cu}, \mathrm{Fe}$ sulfides in Sample 649G-1D-1, 23-26 cm, is puzzling because high-temperature hydrothermal fluids debouching on the seafloor are well known to be magnesium poor (Edmond et al., 1979). The oceanic crust acts as a sink for seawater $\mathrm{Mg}$, not as a source, through the deposition of $\mathrm{Mg}$ silicates during the alteration of basalts.

Talc and other Mg silicates (serpentine, sepiolite, palygorskite) have been reported from several ocean floor hydrothermal deposits. Murdmaa and Rozanova (1976) reported talc and smectite in the Hess Deep bottom sediments. Talc and serpentine are listed among the hydrothermal silicates in the Atlantis II Deep muds, in the Red Sea (Bäcker, 1976; Schneider and Schumann, 1979). Talc is described as an accessory phase in the EPR hydrothermal deposits at $21^{\circ} \mathrm{N}$ (Haymon and Kastner, 1981; Goldfarb et al., 1983). Talc associated with sphalerite and pyrrhotite or with pyrrhotite, marcasite, and 

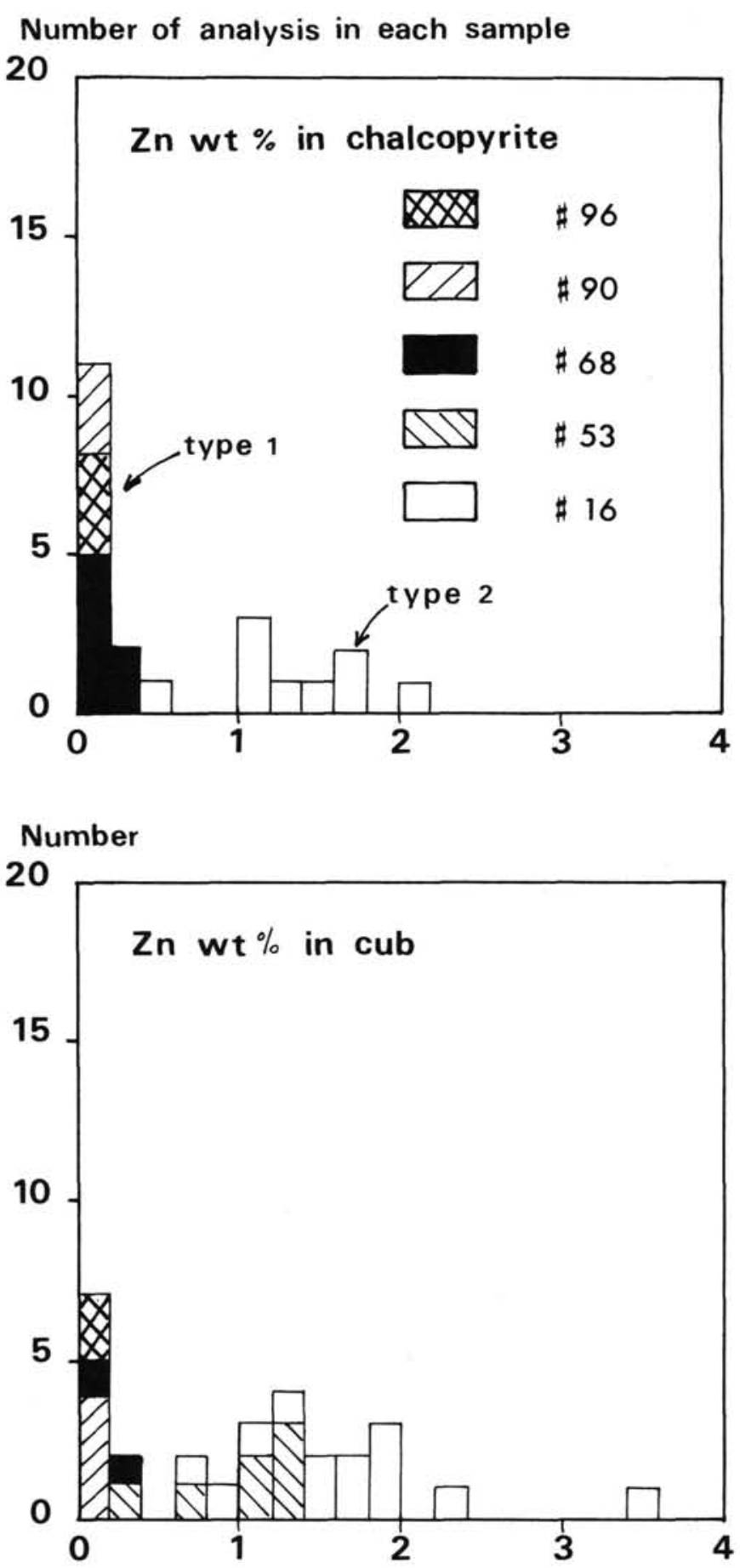

Figure 17. Histograms of $\mathrm{Zn}$ content in wt $\%$ in chalcopyrite and cubic cubanite from type 1 and type 2 samples.

lepidocrocite was observed in the sediment-hosted hydrothermal sulfide deposits of the Guaymas basin (Lonsdale et al., 1980; Koski et al., 1985) and the Escabana Trough, south Gorda Ridge (Benninger and Koski, 1987) respectively.

Talc could have precipitated in the Snake Pit hydrothermal field as a result of one of the following two possible processes:

1. Talc precipitates during the mixing of seawater with hydrothermal fluids. The former supplies $\mathrm{Mg}$ and the latter $\mathrm{SiO}_{2}$ (aq.). This is the hypothesis put forth by Koski et al. (1985) for the talc of the southern Trough of the Guaymas
Basin. That the Snake Pit hydrothermal solutions carry significant $\mathrm{SiO}_{2}$ (aq.) is proved by the presence of amorphous silica as a late-forming phase in sulfide deposits of the Snake Pit. Talc is the stable Mg-silicate at such high $\mathrm{SiO}_{2}$ (aq.) activities.

2. Talc precipitates from hydrothermal solutions which have reacted with uplifted upper mantle ultramafics. A body of serpentinized peridotites was drilled at nearby Site 670 during Leg 109 (this volume). According to Seyfried and Dibble (1980), ultramafics react with seawater, at temperatures higher than $300^{\circ} \mathrm{C}$, to give a $\mathrm{Mg}$-hydroxysulfate which dissolves at lower temperature. $\mathrm{Mg}$ then can react with $\mathrm{SiO}_{2}$ (aq.) to form various silicates such as serpentine, sepiolite, palygorskite, or talc depending on the prevailing conditions. However, precipitation of hydrated magnesium silicates is relatively slow at low temperatures. Hence the solutions resulting from seawater/ultramafics reactions could momentarily become enriched in $\mathrm{Mg}$ and dissolved silica (Nesbitt and Bricker, 1978). Most oceanic serpentine appears to have formed at temperatures lower than $250^{\circ} \mathrm{C}$ (Bonatti et al., 1984; Wenner and Taylor, 1971), whereas talc forms at higher temperatures (Seyfried and Dibble, 1980; and references therein).

We presently lack evidences to support a relationship between the talc and hydrothermal serpentinization of the nearby ultramafic outcrop. Moreover talc has also been found in hydrothermal environments which are not in the vicinity of known ultramafic bodies, e.g., EPR at $21^{\circ} \mathrm{N}$. On the other hand, the intimate talc/Cu, Fe sulfides association suggests talc precipitation from a seawater-derived $\mathrm{Mg}^{++}$and a hydrothermal $\mathrm{SiO}_{2}$. The recurring alternation of talc and sulfides could be due to fluctuations during the mixing of seawater with the hydrothermal fluids through the permeable sulfide mounds or chimneys.

\section{CONCLUSIONS}

The sulfide mound below an active chimney of the Snake Pit hydrothermal field which was drilled during ODP Leg 106 is composed of sulfide fragments with minor amorphous silica and talc. Save for an exceptional piece of intergrown $\mathrm{Cu}, \mathrm{Fe}$ sulfides and talc, the fragments are of three types, characterized by their major sulfide phases: (1) relatively rich in pyrrhotite, the latter exhibiting a tablet habit with lesser amounts of cubic cubanite/chalcopyrite intergrowths, sphalerite, and pyrite; (2) rich in cubic cubanite/chalcopyrite intergrowths with interstitial pyrite, pyrrhotite, and marcasite. Covellite and a bornite-like mineral locally replace the $\mathrm{Cu}, \mathrm{Fe}$ sulfides; (3) sphalerite-rich with rare altered pyrrhotite tablets, $\mathrm{Cu}, \mathrm{Fe}$ sulfide relics, and marcasite. Small amorphous silica spherules are perched on the sulfides.

These mineral associations correspond to nonequilibrium conditions during the precipitation of the sulfides on the seafloor, probably as a result of turbulent mixing between hydrothermal fluids and seawater. Type 2 could represent broken pieces of chimneys as suggested by the massive pieces drilled in Hole 649G.

The large collection of drilled samples studied indicates that the sulfide mound of the Snake Pit hydrothermal field is essentially made up of the same mineral species already described in other sulfide deposits of Pacific active ridges with the exception of the bornite-like mineral. Moreover, almost no sulfate (except in a few pyrrhotite pseudomorphs) and no sulfosalts were observed in the Atlantic samples. The abundance of cubic cubanite/chalcopyrite intergrowths, the high $\mathrm{Cu}$ content of the bulk samples, and the frequency of often fresh pyrrhotite are characteristic of high-temperature hydro- 
thermal deposits. We know now that fluids venting from the Snake Pit chimneys have temperatures venting up to $350^{\circ} \mathrm{C}$. The presence of covellite and the bornite-like mineral locally replacing the $\mathrm{Cu}, \mathrm{Fe}$ sulfides indicate that late supergene alteration occurs in the mound. This process could be due to the observed abundant percolation of diffuse fluids $\left(220^{\circ} \mathrm{C}\right)$. On the other hand, late low-temperature oxidation products such as goethite are relatively rare. All these observations confirm the state of freshness of the Snake Pit hydrothermal deposit which can nevertheless be called a "mature mound" on the basis of its size and morphology. The bulk chemical composition of some samples from Hole 649B representative of 6.5 -m-thick section through the Snake Pit sulfide deposit (about $17 \mathrm{~m}$ away from the active chimney) shows a high copper content $(12 \mathrm{wt} \%)$ and a high Au concentration $(600$ $\mathrm{ppb})$. The $600-\mathrm{ppb}$ average Au content is well above the 200 -ppb background level of oceanic sulfides and is in line with the maturity stage of the mound. Au would be reconcentrated by lower temperature diffuse percolation of hydrothermal fluids.

The only peculiar mineral paragenesis observed in the Snake Pit sulfides is the talc-cubic cubanite/chalcopyrite intimate intergrowth, with minor pyrite. The repeated precipitation of talc along with high-temperature $\mathrm{Cu}, \mathrm{Fe}$ sulfides reflects recurrence of high $\mathrm{Mg}$ and $\mathrm{Si}$ activities. The high $\mathrm{Si}$ activity is also evidenced by the presence of amorphous silica as one of the last phases to form. The high $\mathrm{Mg}$ activity is probably due to entrainment and mixing of seawater through the sulfide deposit during the discharge of hydrothermal fluids.

This study is only preliminary. It will be extended by the study of samples collected by submersible vessels. These will provide further information on the relationships among the different rock types and complete the sampling with pieces of chimneys which could not be drilled. The hydrothermal processes and mineral deposition of the Snake Pit field can only be understood with this additional information.

\section{ACKNOWLEDGMENTS}

We would like to thank Elizabeth Wright and an anonymous reviewer for their constructive suggestions. We also thank Jean-Louis Crovisier for making ready the Debye-Scherrer diffraction apparatus, Phillipe Karcher for his help with SEM-EDS analyses, and Gérard Kremp for preparing the magnetic colloidal solution. We thank A. Malahoff for supplying samples of the massive sulfide deposit from the Galapagos Spreading Center for comparison. This work was supported by a grant of the ASP-ODP.

\section{REFERENCES}

Auclair, G., Fouquet, Y., and Bohn, M., 1987. Distribution of selenium in high temperature hydrothermal sulfide deposits at $13^{\circ} \mathrm{N}$, East Pacific Rise. Can. Miner., 25:577-587.

Bäcker, H., 1976. Fazies und chemische Zusammenstetzung rezenter Auställungen aus Mineralquellen im Roten Meer. Geol. Jahrb., Reihe D, 17:151-172.

Bäcker, H., Lange, J., and Marchig, V., 1985. Hydrothermal activity and sulfide formation in axial valley of the East Pacific Rise crest between 18 and $22^{\circ}$ S. Earth Planet. Sci. Lett., 72:9-22.

Benninger, L. M., and Koski, R. A., 1987. Descriptions and chemical analyses of sulfide samples dredged in 1986 from Escabana Trough, Southern Gorda Ridge. U.S. Geol. Surv. Open-File Rept., 87-375B.

Bischoff, J. L., Rosenbauer, R. J., Aruscavage, P. J., Baedecker, P. A., and Crock, J. G., 1983. Sea-floor massive sulfide deposits from $21^{\circ} \mathrm{N}$, East Pacific Rise, Juan de Fuca Ridge and Galapagos Rift: bulk chemical composition and economic implications. Econ. Geol., 78:1711-1720.

Bonatti, E., Lawrence, J. R., and Morandi, N., 1984. Serpentinization of oceanic peridotites: temperature dependence of mineralogy and boron content. Earth Planet. Sci. Lett., 70:88-94.
Bougault, H., Charlou, J. L., Fouquet, Y., Needham, H. D., and Appriou, P., 1988. Activité hydrothermale entre les zones de fracture $15^{\circ} 20^{\prime} \mathrm{N}$ et $\mathrm{KANE}$ (MAR). Colloque National sur l'Hydrothermalisme Océanique, Brest, 72-74.

Cabri, I. J., 1973. New data on phase relations in the Cu-Fe-S system. Econ. Geol., 68:443-454.

Detrick, R. S., Ryan, W.B.F., Mayer, L., Fox, P. J., Kong, L., Manchester, K., Kastens, K., Karson, J. A., and Pockalny, R., 1985. Mid-Atlantic Ridge/Kane fracture zone final site survey report. Prepared for Joint Oceanographic Institutions.

Edmond, J. M., Measures, C., McDuff, R. E., Chan, L. H., Collier, R., Grant, B., Gordon, L. I., and Corliss, J. B., 1979. Ridge-crest hydrothermal activity and the balances of the major and minor elements in the ocean: the Galapagos data. Earth Planet. Sci. Lett., 46:1-18.

Gente, P., Mével, C., Auzende, J. M., Cannat, M., Donval, J. P., Dubois, J., Fouquet, Y., Grimaud, D., Karson, J. A., Ségonzac, M., and Stievenard, M., 1988. Submersible study of the Snake Pit hydrothermal area: first detailed mapping of a MAR black vent field, EOS, 69:1498.

Goldfarb, M. S., Converse, D. R., Holland, H. D., and Edmond, J. M., 1983. The genesis of hot spring deposits on the East Pacific Rise, $21^{\circ}$ N. Econ. Geol., Monogr., 5:184-197.

Hannington, M. D., Peter, J. M., and Scott, S. D., 1986. Gold in seafloor polymetallic sulfide deposits. Econ. Geol., 81:1867-1883.

Hannington, M. D., Thompson, G., Rona, P. A., and Scott, S. D., 1988. Gold and native copper in supergene sulfides from the Mid Atlantic Ridge. Nature, 333:64-66.

Haymon, R. M., and Kastner, M., 1981. Hot spring deposits on the East Pacific Rise at $21^{\circ} \mathrm{N}$ : preliminary description of mineralogy and genesis. Earth Planet. Sci. Lett., 53:363-381.

Hekinian, R., Février, M., Bischoff, J. L., Picot, P., and Shanks, W. C., 1980. Sulfide deposits from the East Pacific Rise near $21^{\circ} \mathrm{N}$. Science, 207:1433-1444.

Hekinian, R., and Fouquet, Y., 1985. Volcanism and metallogenesis of axial and off-axial structures on the East Pacific Rise near $13^{\circ} \mathrm{N}$. Econ. Geol., 80:221-249.

Hoffert, M., Perseil, A., Hekinian, R., Choukroune, P., Needham, H. D., Francheteau, J., and Le Pichon, X., 1978. Hydrothermal deposits sampled by diving saucer in Transform Fault " $A$ " near $37^{\circ} \mathrm{N}$ on the Mid Atlantic Ridge, Famous area. Oceanol. Acta, $1: 73-86$.

Karson, J. A., and Brown, J. R., 1988. Geologic setting of the Snake Pit hydrothermal site: an active vent field on the mid-Atlantic ridge, Mar. Geophys. Res., 10:91-107.

Kong, L., Ryan, W.B.F., Mayer, L., Detrick, R. S., Fox, P. J., and Manchester, K., 1985. Bare-rock drill sites, ODP Legs 106 and 109: evidence for hydrothermal activity at $23^{\circ} \mathrm{N}$ in the Mid-Atlantic Ridge rift valley. EOS, 65:1106.

Koski, R. A., Clague, D. A., and Oudin, E., 1984. Mineralogy and chemistry of massive sulfide deposits from the Juan de Fuca ridge. Geol. Soc. Am. Bull., 95:930-945.

Koski, R. A., Lonsdale, P. F., Shanks, W. C., Berndt, M. E., and Howe, S. S., 1985. Mineralogy and geochemistry of a sediment hosted hydrothermal sulfide deposit from the southern trough of Guaymas basin, Gulf of California. J. Geophys. Res., 90:6695-6707.

Lonsdale, P. F., Bischoff, J. L., Burns, V. M., Kastner, M., and Sweeny, R. E., 1980. A high temperature deposit on the seabed at Gulf of California spreading center. Earth Planet. Sci. Lett., 49:8-20.

MacDonald, K. C., 1982. Geophysical settings for hydrothermal vents and mineral deposits on the East Pacific Rise. Mar. Technol. Soc. J., 16:26-31.

Malahoff, A., 1982. A comparison between the massive submarine polymetallic sulfides of the Galapagos Rift with some continental deposits. Mar. Technol. Soc. J., 16:39-45.

Malahoff, A., Embley, R. W., Cronan, D. S., and Skirrow, R., 1983. The geological setting and chemistry of hydrothermal sulfides and associated deposits from the Galapagos rift at $86^{\circ} \mathrm{W}$. Mar. Mining, $4: 123-137$.

Mével, C., Auzende, J. M., Cannat, M., Donval, J. P., Dubois, J., Fouquet, Y., Gente, P., Grimaud, D., Karson, J. A., Ségonzac, M., and Stievenard, M., 1989. La ride du Snake Pit (dorsale médio-Atlantique, $23^{\circ} 22^{\prime} \mathrm{N}$ ): résultats préliminaires de la campagne HYDROSNAKE. C.R. Acad. Sci. Paris, 308:545-552. 
Murdmaa, I. O., and Rozanova, T. V., 1976. Hess Deep bottom sediments. In Geological-geophysical researches in the southeastern part of the Pacific ocean. Nauka, 252-260.

Nesbitt, H. W., and Bricker, O. P., 1978. Low temperature alteration processes affecting ultramafic bodies. Geochim. Cosmochim. Acta, 42:403-409.

Normark, W. R., Morton, J. L., Koski, R. A., Clague, D. A., and Delaney, J. R., 1983. Active hydrothermal vents and sulfide deposits on the southern Juan de Fuca Ridge. Geology, 11:158-163.

O.D.P. Leg 106 Scientific Party, 1986. Drilling the Snake Pit hydrothermal sulfide deposit on the Mid-Atlantic Ridge. Geology, 14:1004-1007.

Ramdhor, P., 1969. The ore minerals and their intergrowths. Oxford (Pergamon Press), 1174 p.

Rona, P. A., 1982. Metallic sulfides at seafloor spreading centers: a global overview. Mar. Technol. Soc. J., 16:81-86.

Rona, P. A., Klinkhammer, G., Nelsen, T. A., Trefry, J. H., and Elderfield, H., 1986. Black smokers, massive sulfides and vent biota at the Mid-Atlantic Ridge. Nature, 321:33-37.

Schneider, W., and Schumann, D., 1979. Tonminerale in Normalsedimenten hydro-thermal beeinflussten Sedimenten und Erzschlämmen des Roten Meeres. Geol. Rundschau, 68:631-648.

Scott, R. B., Temple, D. G., and Peron, P. R., 1979. Nature of hydrothermal exchange between oceanic crust and seawater at $26^{\circ} \mathrm{N}$ lat., Mid-Atlantic Ridge. In (Ed.) Benthic Boundary Layer Processes, an IOGC Symposium on the Benthic Boundary Layer. Lexington (D.C. Heath and Co).

Scott, S. D., 1974. Experimental methods in sulfide synthesis. In Ribble, P. H. (Ed.), Sulfide Mineralogy. Miner. Soc. Am. Short Courses Notes, 1:51-538.
Seyfried, W. E., and Dibble, W. E., 1980. Seawater peridotites interaction at $300^{\circ} \mathrm{C}$ and 500 bars: implication for the origin of oceanic serpentinites. Geochim. Cosmochim. Acta, 44:309-321.

Sugaki, A., Shima, H., Kitakse, A., and Harada, H., 1975. Isothermal phase relations in the system $\mathrm{Cu}-\mathrm{Fe}-\mathrm{S}$ under hydrothermal conditions at 350 and $300^{\circ} \mathrm{C}$. Econ. Geol., 70:806-823.

Temple, D. G., Scott, R. B., and Rona, P. A., 1979. Geology of a submarine hydrothermal field, Mid-Atlantic Ridge, $26^{\circ} \mathrm{N}$ latitude. J. Geophys. Res., 84:7453-7466.

Thompson, G., Mottl, M. J., and Rona, P. A., 1985. Morphology, mineralogy and chemistry of hydrothermal deposits from the TAG area, $26^{\circ} \mathrm{N}$, Mid-Atlantic Ridge. Chem. Geol., 49:243-257.

Thompson, G., Humphris, S. E., Schroeder, B., Sulanowska, M., and Rona, P. A., 1988. Hydrothermal mineralization on the MidAtlantic Ridge. Can. Miner., 26:697-711.

Wenner, D. B., and Taylor, H. P., 1971. Temperatures of serpentinization of ultramafic rocks based on ${ }^{18} \mathrm{O} /{ }^{16} \mathrm{O}$ fractionation between coexisting serpentine and magnetite. Contrib. Mineral. Petrol., 32:165-185.

Zierenberg, R. A., Shanks, W. C., III, and Bischoff, J. L., 1984. Massive sulfide deposits at $21^{\circ} \mathrm{N}$, East Pacific Rise: chemical composition stable isotopes and phase equilibria. Geol. Soc. Am. Bull., 95:922-929.

Date of initial receipt: 5 July 1988

Date of acceptance: 12 June 1989

Ms 106/109B-137 
Table 6. Representative analyses of $\mathrm{Fe}, \mathrm{Cu}$ sulfides $(\mathrm{cp}=$ chalcopyrite; cub = cubic cubanite; $\mathrm{cv}=$ covellite; bn = bornite-like mineral; nd $=$ not detected).

\begin{tabular}{|c|c|c|c|c|c|c|c|c|c|c|c|c|c|}
\hline $\begin{array}{c}\text { sample } \\
N^{\circ} \\
\text { wt } \%\end{array}$ & $\begin{array}{l}16 \\
\Phi\end{array}$ & $\begin{array}{c}16 \\
c u b\end{array}$ & $\begin{array}{c}\text { type } 1 \\
649 \text { B } 1-8 C \\
53 \\
\text { cub }\end{array}$ & $\begin{array}{c}\text { type } 1 \\
\text { 649B 1-8D } \\
73 \\
\text { cub }\end{array}$ & $\begin{array}{l}90 \\
C P\end{array}$ & $\begin{array}{c}90 \\
\text { cub }\end{array}$ & $\begin{array}{l}68 \\
\Phi\end{array}$ & $\begin{array}{c}68 \\
c u b\end{array}$ & $\begin{array}{l}96 \\
9\end{array}$ & $\begin{array}{l}96 \\
\text { cub }\end{array}$ & $\begin{array}{l}54 \\
\Phi\end{array}$ & $\begin{array}{l}54 \\
\mathrm{cV}\end{array}$ & $\begin{array}{l}54 \\
\text { bn }\end{array}$ \\
\hline$S$ & 31.17 & 35.29 & 34.97 & 34.84 & 35.43 & 35.25 & 34.97 & 35.36 & 35.27 & 35.95 & 35.53 & 33.59 & 33.84 \\
\hline$Z n$ & 1.63 & 1.29 & 1.15 & 0.28 & 0.15 & 0.04 & 0.10 & 0.11 & 0.04 & 0.10 & 0.01 & nd & nd \\
\hline $\mathrm{Cd}$ & 0.02 & nd & nd & nd & nd & nd & nd & nd & 0.04 & 0.03 & nd & nd & nd \\
\hline Co & nd & nd & nd & nd & 0.04 & 0.18 & 0.05 & 0.31 & 0.02 & 0.10 & 0.02 & nd & 0.04 \\
\hline $\begin{array}{l}\text { Total } \\
\text { at } \%\end{array}$ & 98.67 & 99.80 & 99.90 & 99.39 & 99.69 & 99.96 & 100.54 & 100.55 & 99.03 & 99.33 & 99.36 & 99.99 & 99.18 \\
\hline $\mathrm{Fe}$ & 25.90 & 33.42 & 34.83 & 35.25 & 25.55 & 30.60 & 26.27 & 34.57 & 25.47 & 33.43 & 24.55 & 1.19 & 13.10 \\
\hline $\mathrm{Cu}$ & 22.80 & 15.75 & 14.91 & 15.08 & 23.71 & 14.19 & 23.87 & 15.20 & 23.78 & 15.62 & 24.53 & 48.80 & 37.00 \\
\hline Zn & 1.16 & 0.90 & 0.80 & 0.20 & 0.11 & 0.03 & 0.07 & 0.08 & 0.03 & 0.07 & 0.01 & nd & nd \\
\hline Cd & 0.01 & nd & nd & nd & nd & nd & nd & nd & 0.02 & 0.01 & nd & 0.01 & nd \\
\hline Co & nd & nd & nd & nd & 0.03 & 0.14 & 0.04 & 0.24 & 0.02 & 0.08 & 0.02 & nd & 0.03 \\
\hline
\end{tabular}

Number

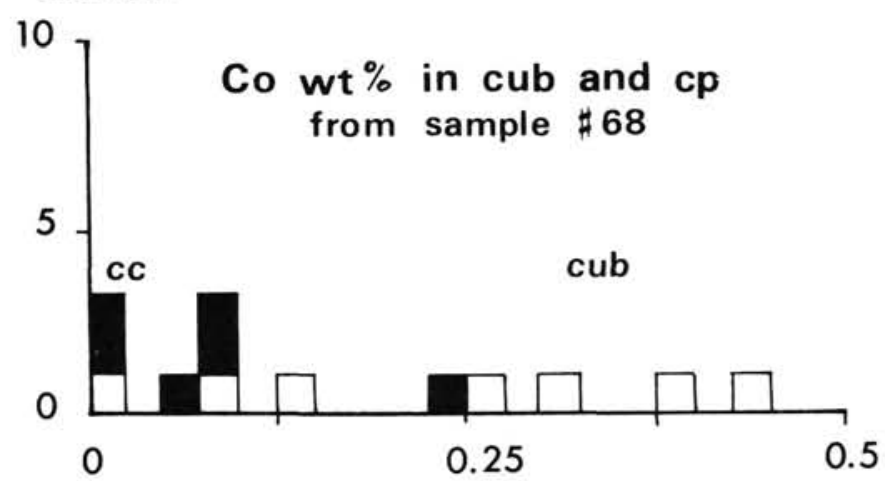

Number

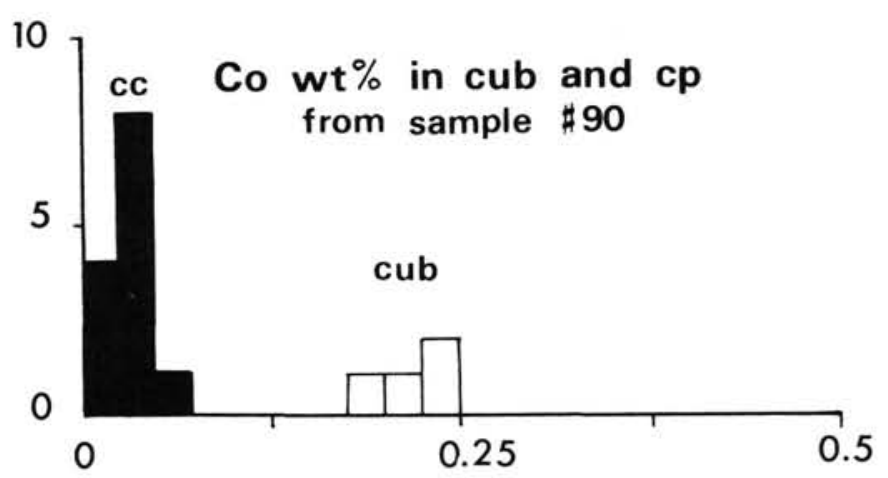

Figure 18. Histograms of Co content in wt\% in associated chalcopyrite and cubic cubanite from Samples 649B-1D-8D, \#68, and 649B$1 \mathrm{D}-8 \mathrm{E}$, \#90 (type 2).

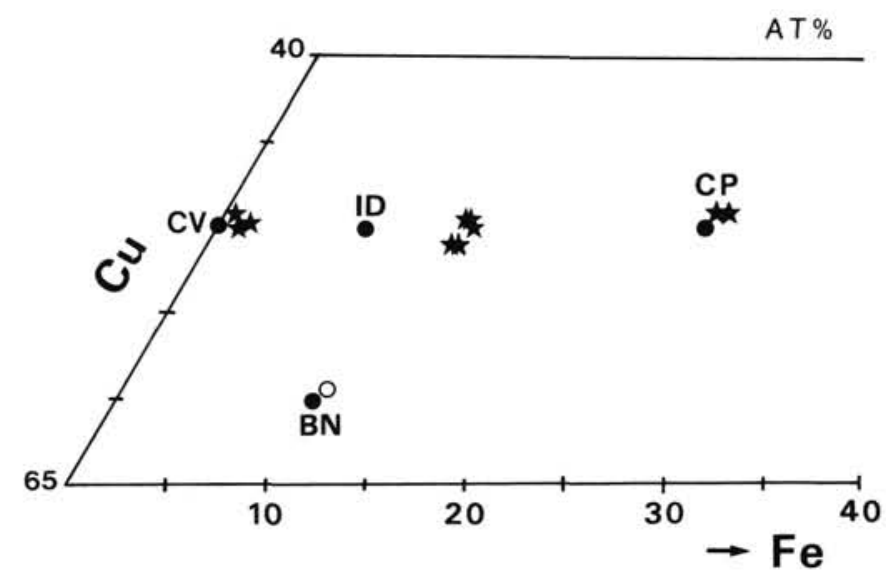

Figure 19. Compositions of chalcopyrite, covellite, and bornite-like mineral from Sample 649B-1-8C, \#54, in a portion of the $\mathrm{Fe}-\mathrm{Cu}-\mathrm{S}$ ternary diagram (black stars). Covellite (CV), idaite (ID), bornite $(\mathrm{BN})$, and chalcopyrite (CP) end-members (solid circles) as well as the "anomalous bornite" from Goldfarb et al. (1983) (empty circle) are shown for comparison. 


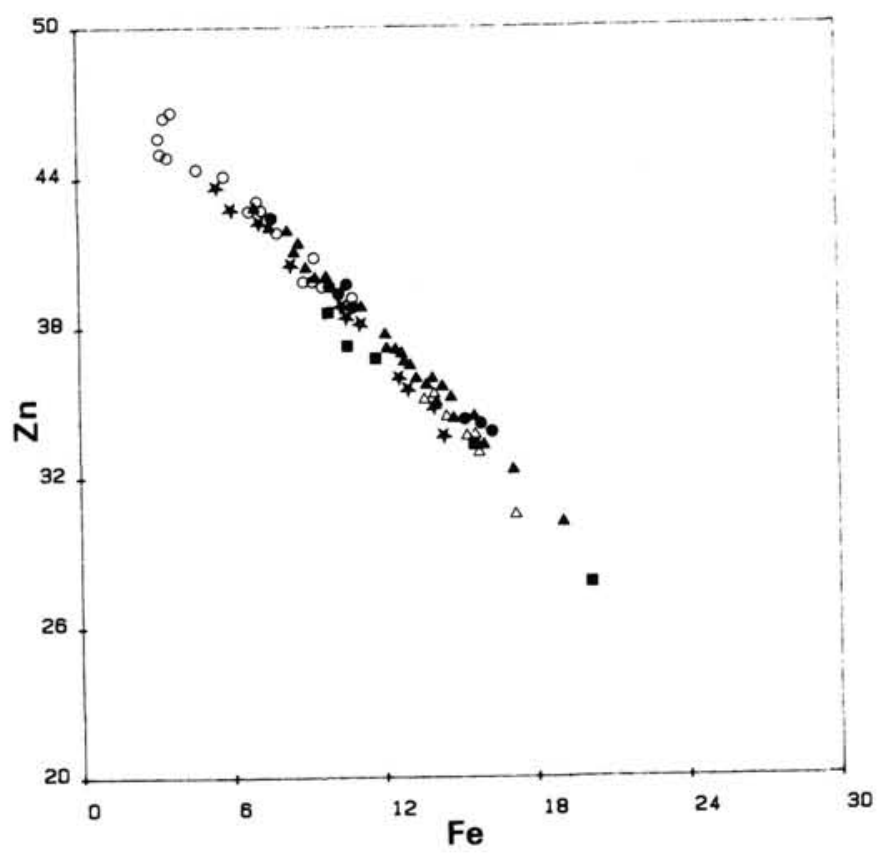

Figure 20. Sphalerite compositions in a Fe vs. $\mathrm{Zn}$ wt\% binary diagram. Type 1: solid triangles = Sample 649B-1-8, \#16; solid circles $=$ Sample 649B-1-8C, \#5 solid squares = Sample 649B-1-8E, \#93; type 2 : empty triangles $=$ Sample 649B-1-8D, \#73; empty circles $=$ Sample 649B-1-8E, \#90; type 3: solid stars = Sample 649B-1-8, \#17.

Table 7. Representative analyses of sphalerites $(\mathrm{c}=$ core or close to contact with $\mathrm{Cu}, \mathrm{Fe}$ sulfide core; $\mathrm{r}=$ rim of a single crystal; max $=$ maximum iron content $; \min =$ minimum iron content $;$ nd $=$ not detected $)$.

\begin{tabular}{|c|c|c|c|c|c|c|c|c|c|c|c|c|}
\hline \multirow{3}{*}{$\begin{array}{c}\text { type } \\
\text { sample } \\
N^{\circ} \\
\text { wt } \%\end{array}$} & \multicolumn{2}{|c|}{$\begin{array}{c}1 \\
649 \mathrm{~B} 1-8\end{array}$} & \multicolumn{2}{|c|}{$\begin{array}{c}1 \\
649 B 1-8 C\end{array}$} & \multicolumn{2}{|c|}{$\begin{array}{c}1 \\
649 \mathrm{~B} 1-8 \mathrm{E}\end{array}$} & \multicolumn{2}{|c|}{$\begin{array}{c}2 \\
649 B 1-8 D\end{array}$} & \multicolumn{2}{|c|}{$\begin{array}{c}2 \\
649 B 1-8 E\end{array}$} & \multicolumn{2}{|c|}{$\begin{array}{c}2 \\
649 B 1-8\end{array}$} \\
\hline & 16 & 16 & 53 & 53 & 93 & 93 & 73 & 73 & 90 & 90 & 17 & 17 \\
\hline & $\max$ & $\min$ & $\max$ & $\min$ & $\max$ & $\min$ & c & $r$ & c & $r$ & C & $r$ \\
\hline S & 33.24 & 32.65 & 33.26 & 33.01 & 34.75 & 34.53 & 33.85 & 34.02 & 32.89 & 32.33 & 33.51 & 34.07 \\
\hline $\mathrm{Fe}$ & 22.26 & 8.60 & 18.79 & 8.93 & 18.70 & 11.74 & 18.60 & 16.62 & 12.67 & 3.98 & 16.56 & 6.49 \\
\hline $\mathrm{Cu}$ & 0.53 & 0.59 & 0.16 & 0.25 & nd & 0.21 & 0.08 & 0.03 & 0.54 & 0.30 & 1.99 & ne \\
\hline $\mathrm{Zn}$ & 40.80 & 56.00 & 46.86 & 57.70 & 46.32 & 43.07 & 46.85 & 48.87 & 53.11 & 61.62 & 47.96 & 59.40 \\
\hline $\mathrm{Cd}$ & 0.79 & 0.09 & 0.36 & 0.12 & 0.33 & 0.25 & 0.15 & 0.02 & 0.13 & nd & 0.19 & 0.13 \\
\hline Co & nd & nd & nd & nd & 0.04 & 0.06 & nd & nd & 0.30 & 0.37 & nd & nd \\
\hline Total & 97.64 & 97.93 & 99.43 & 100.01 & 100.14 & 99.86 & 99.53 & 99.56 & 99.64 & 98.60 & 100.21 & 100.09 \\
\hline at $\%$ & & & & & & & & & & & & \\
\hline $\mathrm{S}$ & 49.96 & 49.94 & 49.49 & 49.57 & 50.87 & 51.15 & 50.08 & 50.36 & 49.31 & 49.59 & 49.57 & 50.88 \\
\hline $\mathrm{Fe}$ & 19.21 & 7.55 & 16.05 & 7.70 & 15.71 & 9.98 & 15.80 & 14.12 & 10.91 & 3.50 & 14.06 & 5.56 \\
\hline $\mathrm{Cu}$ & 0.40 & 0.46 & 0.12 & 0.19 & nd & 0.16 & 0.06 & 0.02 & 0.41 & 0.23 & 1.49 & no \\
\hline $\mathrm{Zn}_{\mathrm{n}}$ & 30.09 & 42.01 & 34.19 & 42.49 & 33.25 & 38.56 & 34.00 & 35.48 & 39.06 & 46.36 & 34.80 & 43.50 \\
\hline Cd & 0.34 & 0.04 & 0.15 & 0.05 & 0.14 & 0.11 & 0.06 & 0.01 & 0.06 & nd & 0.08 & 0.06 \\
\hline Co & nd & nd & nd & nd & 0.03 & 0.05 & nd & nd & 0.24 & 0.31 & nd & no \\
\hline
\end{tabular}



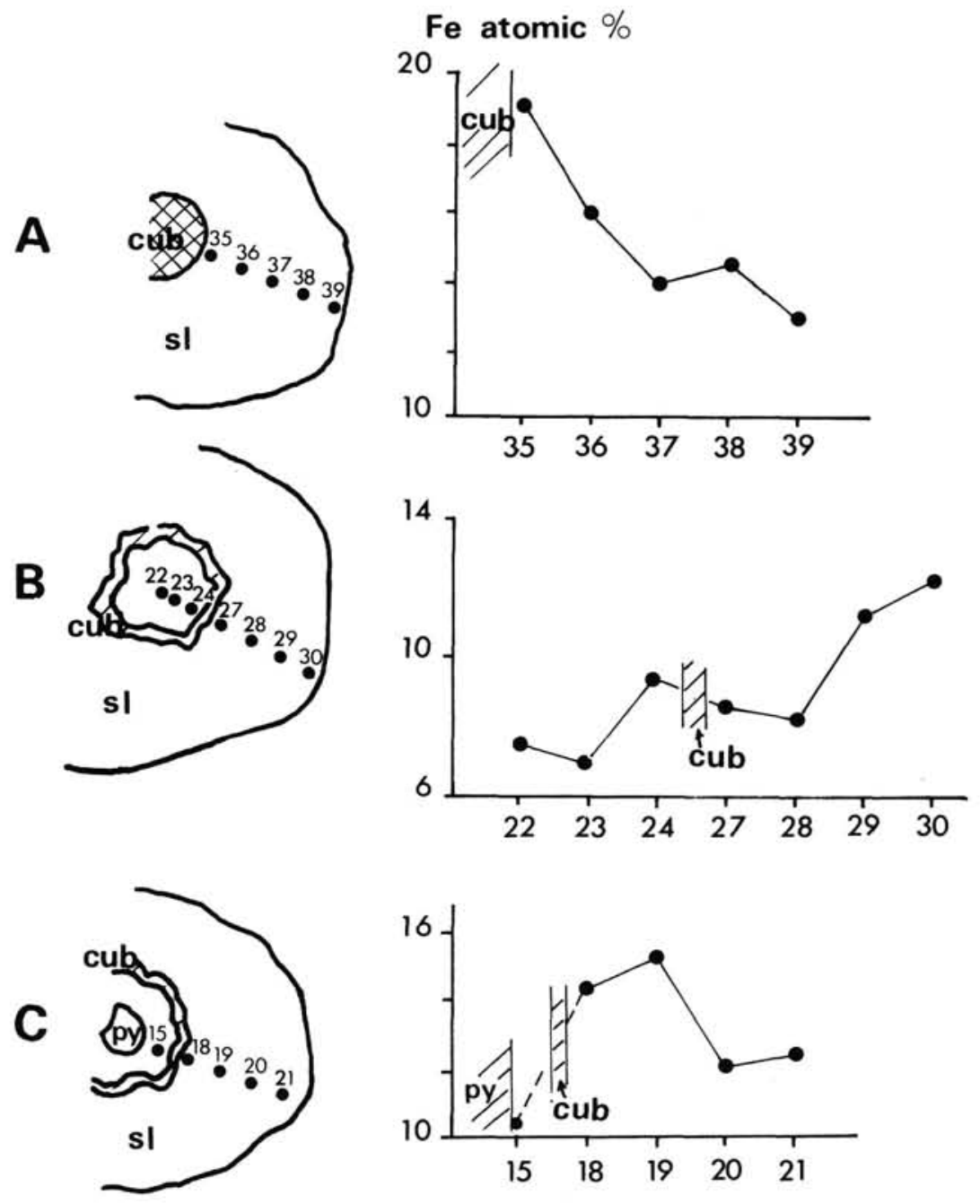

Figure 21. Examples of zoned sphalerite crystals from Sample 649B-1D-8, \#16. A = crystals with a cubic cubanite/chalcopyrite (cub) core; $\mathrm{B}=$ crystal with an intermediate layer of cubic cubanite/chalcopyrite; $\mathrm{C}=$ crystal with a pyrite core and an intermediate cubic cubanite/chalcopyrite (cub) layer.

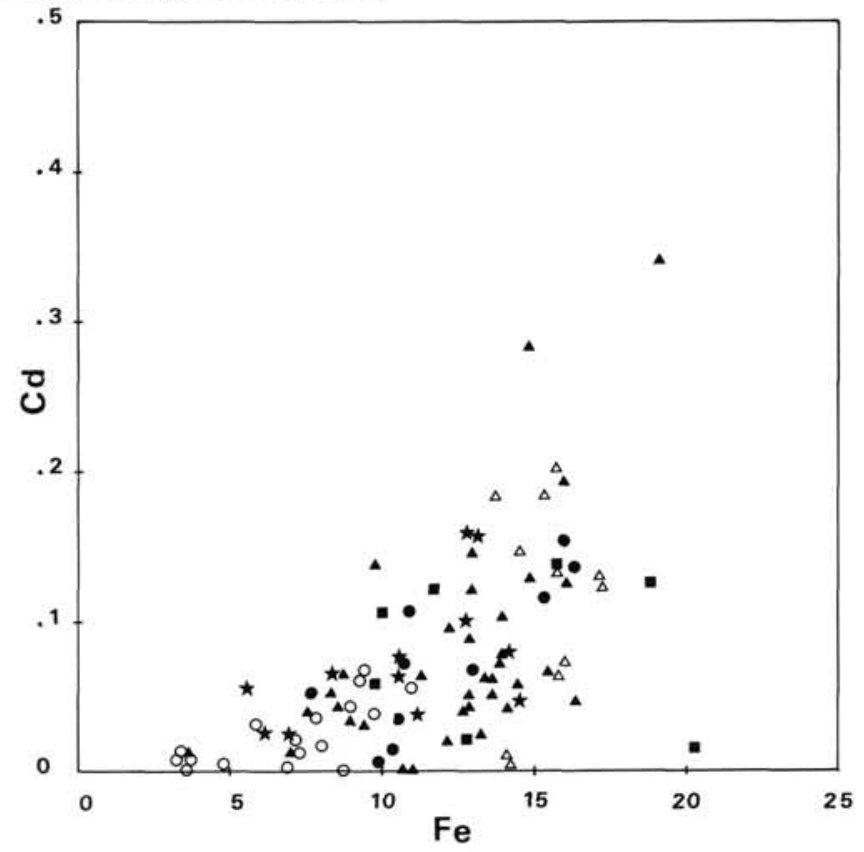

Figure 22. Compositions of sphalerites in a Fe vs. Cd wt\% binary diagram. Symbols same as in Figure 20. 